Review Article

\title{
"Cara inchada" of cattle, an infectious, apparently soil antibiotics-dependant periodontitis in Brazil ${ }^{1}$
}

\author{
Jürgen Döbereiner ${ }^{2}$, Iveraldo S. Dutra ${ }^{3}$, Ivan V. Rosa ${ }^{4}$ and Hans Blobel ${ }^{5}$
}

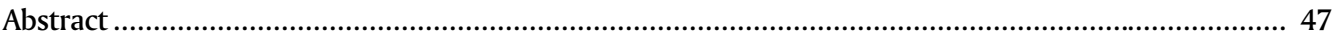

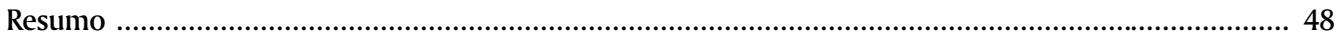

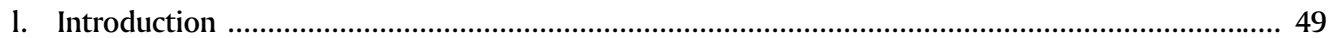

2. Disease history, clinical signs and pathological alterations of "cara inchada" in cattle (CI) ............ 49

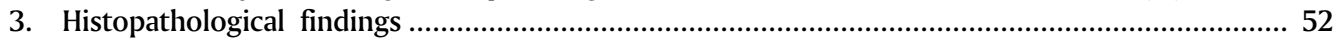

4. There is no scientific evidence of a mineral involvement in the etiology of $\mathrm{Cl}$............................ 54

5. Bacterial isolations from periodontal $\mathrm{Cl}$-lesions ........................................................................ 55

6. Characterization of anaerobic bacteria isolated from periodontal $\mathrm{Cl}$-lesions ................................ 55

7. Cattle affected by Cl-periodontitis recovered after their transfer to a $\mathrm{Cl}$-free area ........................ 55

8. Panicum maximum-pastures free of weeds appeared to contain a determinant factor for the development of $\mathrm{Cl}$-periodontitis .................................................................................... 56

9. Bacteriological monitorship of the regression and cure of $\mathrm{Cl}$-periodontitis ................................. 56

10. Confinement of calves affected by $\mathrm{CI}$ led to healing of the periodontal lesions ........................... 57

11. Avoidance of burning the cut forest did not help to recover $\mathrm{Cl}$-calves from the disease .................. 57

12. The milk of the mother-cows, kept on Cl-prone pastures, seemed to contain the supposed determinant factor for development of the periodontitis in their calves ....................................... 58

13. Occurrence of $\mathrm{Cl}$ in the "Cerrado" (tree-savanna) after its first cultivation for pasture formation .. 58

14. Outbreak of $\mathrm{CI}$ in the "High Pantanal" of Mato Grosso after the first cultivation of a virgin area with Panicum maximum-grass .............................................................................................. 58

15. Renewed outbreaks of CI on farms, when long-standing undisturbed soils were freshly cultivated for pasture improvement or forage production .................................................................... 58

16. Inefficiency of parenteral administration of antibiotics for the treatment of Cl-periodontitis ........ 59

17. The effect of antibiotics given as additives in mineral mixtures to prevent Cl-periodontitis ............ 59

18. Efficacy of orally administered virginiamycin for the recovery of calves from Cl-periodontitis ........ 59

19. "Cara inchada" and cellular immunity .................................................................................. 59

20. Modification of the soil microflora after the first cultivation of virgin soils or after new cultivation of long-standing undisturbed soils in former $\mathrm{Cl}$-prone areas ......................................................6 60

21. Streptomycin and actinomycin increase the adherence on oral epithelial cells of the Bacteroides melaninogenicus group associated with the periodontal CI-lesions ........................................... 60

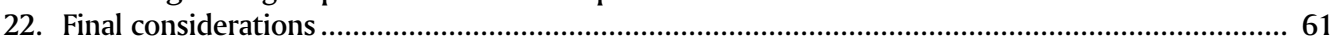

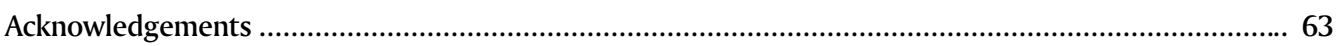

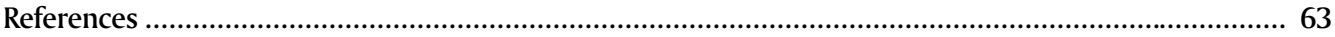

ABSTRACT.- Döbereiner J., Dutra I.S., Rosa I.V. \& Blobel H. 2000. "Cara inchada” of cattle, an infectious, apparently soil antibiotics-dependant periodontitis in Brazil. Pesquisa Veterinária Brasileira 20(2):47-64. Projeto Sanidade Animal Embrapa/UFRRJ, Km 47, Seropédica, Rio de Janeiro 23851-970, Brazil.

The objective of this review on the investigation of "cara inchada" in cattle $(\mathrm{CI})$, pursued over the last 30 years, was to elucidate the pathogenicity of the disease and come to proper

\footnotetext{
${ }^{1}$ Accepted for publication on November 3, 1999.

2 Embrapa-CNPAB/PSA-Projeto Sanidade Animal Embrapa/UFRRJ, Km 47, Seropédica, RJ 23851-970, Brazil; Research Fellow CNPq (309294/88-1).

${ }^{3}$ Curso de Medicina Veterinária/DAPSA, Unesp-Campus de Araçatuba, Caixa Postal 533, Araçatuba, SP 16015-050, Brazil; Research Fellow CNPq (305967/85-1).
}

\footnotetext{
${ }^{4}$ Former Researcher of Embrapa-CNPGC, Campo Grande, MS. Present address: Rua 60, no.288, Nova Campo Grande, 79104-360 Campo Grande, MS, Brazil.

${ }^{5}$ Prof.Emeritus, Fakultät für Veterinärmedizin, Justus-Liebig-Universität Giessen, Frankfurter Str. 107, D-35392 Giessen, Germany.
} 
conclusions on its etiology. $\mathrm{CI}$ has been widely considered to be of nutritional origin, caused primarily by mineral deficiency or imbalance. However, the disease consists of a rapidly progressive periodontitis, affecting the periodontal tissues at the level of the premolars and molars during the period of tooth eruption generally starting in young calves. The disease led to great economic losses for farmers in central-western Brazil, after the occupation of new land for cattle raising in the 1960s and 1970s. The lateral enlargement of the maxillary bones of affected calves gave the disease the popular name of "cara inchada", i.e., swollen or enlarged face. The enlargement was found to be due to a chronic ossifying periostitis resulting from the purulent alveolitis of Cl. Black-pigmented non-saccharolytic Bacteroides melaninogenicus, always together with Actinomyces (Corynebacterium) pyogenes, were isolated in large numbers from the periodontal lesions. B. melaninogenicus could be isolated in small numbers also from the marginal gingiva of a few healthy calves maintained on Cl-free farms. "In vitro"-assays showed that streptomycin and actinomycin, as well as the supernatants of cultivates of actinomycetes from soils of $\mathrm{Cl}$-prone farms, applied in subinhibitory concentrations to the bacteria tested, enhanced significantly (up to 10 times) the adherence of the black-pigmented B.melaninogenicus to epithelial cells of the bovine gingiva. The antibiotics are apparently produced in large quantities by the increased number of soil actinomycetes, including the genus Streptomyces, that develop when soil microflora are modified by cultivating virgin forest or "Cerrado" (tree-savanna) for the first time for cattle grazing. The epidemiology of $\mathrm{Cl}$ now provides strong evidence that the ingestion with the forage of such antibiotics could possibly be an important determinant factor for the onset and development of this infectious periodontitis. The antibiotic enhanced adherence of B.melaninogenicus to the sulcus-epithelium of the marginal gingiva, is thought to allow it to colonize, form a plaque and become pathogenic. There is experimental evidence that this determinant factor for the development of the periodontitis is present also in the milk of the mothers of Cl-diseased calves. It has been shown that the bacteria isolated from the periodontal Cl-lesions produce enzymes and endotoxins capable of destroying the periodontal tissues. The epidemiology of $\mathrm{Cl}$, with its decline in incidence and its disappearance after several years, could be explained by the fact that the former equilibrium of the microflora of the once undisturbed virgin soil has been reached again and that the number of antibiotic producing actinomycetes has been anew reduced. By this reasoning and all the data available, $\mathrm{CI}$ should be considered as a multifactorial infectious disease, caused primarily by the anaerobic black-pigmented non-saccharolytic Bacteroides melaninogenicus, always together with the micro-anaerobic Actinomyces pyogenes. Accordingly, the onset and development of the infectious periodontitis is apparently determined by ingestion with the forage of subinhibitory concentrations of antibiotics produced in recently cultivated virgin soils. This hypothesis is supported by the recent observation of renewed outbreaks of Cl-periodontitis in former Cl-prone areas, following fresh cultivation after many years. The infectious nature of $\mathrm{Cl}$ is confirmed by trials in which virginiamycin was used efficiently for the oral treatment of Cl-diseased cattle. Previously it has been shown, that spiramycin and virginiamycin, used as additives in mineral supplements, prevented $\mathrm{Cl}$ periodontitis.

INDEX TERMS: “Cara inchada”, cattle, periodontitis, Bacteroides melaninogenicus, determinant factor, soil antibiotics, streptomycin, actinomycin.

RESUMO.- [“Cara inchada” dos bovinos, uma periodontite infecciosa, aparentemente desencadeada por antibióticos do solo.] O objetivo desta revisão das pesquisas sobre a "cara inchada" dos bovinos (CI), realizadas no decorrer dos últimos 30 anos, é de elucidar melhor a sua etiologia. A CI geralmente tem sido considerada de origem nutricional, causada primariamente por deficiência ou desequilíbrio mineral. A doença caracteriza-se por uma periodontite rapidamente progressiva, que afeta os tecidos peridentários a nível dos premolares e molares no período de erupção dos dentes e que se inicia geralmente em bezerros jovens. A doença causou grandes perdas econômicas aos pecuaristas da Região
Centro-Oeste do Brasil, nas décadas de 1960 e 1970, com a ocupação de novas terras para criação de gado. $O$ frequiente abaulamento lateral dos ossos maxilares nos bezerros, que deu à doença o nome popular de "cara inchada", foi demonstrado ser conseqüente à periostite crônica ossificante resultante da alveolite purulenta da CI. Das lesões peridentárias foi isolado, em grande número, Bacteroides melaninogenicus, sempre junto com Actinomyces (Corynebacterium) pyogenes. Bactérias classificadas como pertencentes ao grupo sacarolítico e não-sacarolítico dos pigmentados de negro Bacteroides melaninogenicus e Bacteroides spp também foram isoladas, em pequeno número, de bovinos jovens sadios de fazendas $\mathrm{Cl}$ - 
negativas. Ensaios "in vitro" mostraram que os antibióticos estreptomicina e actinomicina, bem como os sobrenadantes de cultivos de actinomicetos do solo de fazendas CI-positivas, aplicadas nas bactérias ensaiadas em concentrações subinibidoras, aumentaram significativamente (até 10 vezes) a aderência de B.melaninogenicus a células epiteliais da gengiva bovina. Esses antibióticos são produzidos no solo em conseqüência de um aumento do número de actinomicetos, incluindo os do gênero Streptomyces, quando há modificação de sua microbiota em áreas previamente ocupadas por mata virgem ou vegetação natural de Cerrado, que foram cultivadas pela primeira vez na formação de pastagem para o gado. Em face da epidemiologia da $\mathrm{CI}$, há fortes evidências de que a ingestão desses antibióticos pelos bovinos, junto com a forrageira, seja importante fator desencadeante para o desenvolvimento da periodontite. Através do aumento da aderência de $B$. melaninogenicus ao epitélio da gengiva marginal, em face da ingestão dos antibióticos pelos animais, as bactérias conseguem colonizar, formar a placa bacteriana e tornarse patogênicas. Há evidência de que o fator desencadeante (aparentemente, os antibióticos) esteja também presente no leite de vacas-mães de bezerros afetados pela $\mathrm{CI}$. Foi demonstrado que as bactérias envolvidas na periodontite produzem enzimas e endotoxinas capazes de ação destrutiva sobre os tecidos peridentários. A epidemiologia da $\mathrm{CI}$, com a diminuição de sua incidência e o seu desaparecimento no decorrer dos anos, pode ser explicada pelo fato de que o prévio equílibrio da microbiota no solo virgem foi alcançado novamente e a produção dos antibióticos se reduziu. Desta maneira, a $\mathrm{CI}$ deve ser considerada como uma periodontite infecciosa multifatorial, causada sobretudo por bactérias anaeróbias pertencentes ao grupo Bacteroides melaninogenicus e, ao que tudo indica, desencadeada pela ingestão contínua, com a forrageira, de concentrações subinibidoras de antibióticos de solos recentememente cultivados. Esta hipótese é reforçada pela observação recente de novos surtos de $\mathrm{CI}$, em áreas anteriormente positivas para a doença, em consequiência da reforma de pastagens e capineiras após muitos anos. A natureza infecciosa da $\mathrm{Cl}$-periodontite foi confirmada através de experimento, em que virginiamicina mostrou-se eficaz no tratamento oral de bovinos afetados pela doença. Os antibióticos espiramicina e virginiamicina, usados como aditivos em suplementos minerais no campo, mostraram-se eficientes na prevenção da $\mathrm{CI}$.

TERMOS DE INDEXAÇÃO: "Cara inchada", bovinos, periodontite, Bacteroides melaninogenicus, fator desencadeante, antibióticos do solo, estreptomicina, actinomicina.

\section{Introduction}

There occur two animal diseases in Brazil with the popular name of "cara inchada", i.e., "swollen" or "enlarged face". One disease is the well known fibrous osteodystrophy in horses determined by secondary hyperparathyroidism, due to calcium/phosphorus imbalance; the other disease, of different etiology, is "cara inchada" of cattle $(\mathrm{CI})$, characterized by a rapidly progressive periodontitis with its onset mainly in young calves, often leading to lateral enlargement of the face.

Page \& Schroeder (1982), in their comparative review on "Periodontitis in Man and Other Animals", stressed that $\mathrm{CI}$ is of particular interest. They wrote: ... "the few data available project a dramatic and scientifically challenging picture. ... It is notable that the disease symptoms found around premolars and molars are typical of those caused by infection, especially when seen in the light of comparative pathology." And further on they continued: "Nevertheless, the clinical and histopathological characteristics of the periodontitis lesions in cattle call for an explanation consistent with bacterial infection." From this it follows, that Page and Schroeder, with their considerable experience shown in their detailed review on comparative periodontitis, concluded that $\mathrm{CI}$ has to be considered an infectious disease; but they "call for an explanation" of how the infection may develop and what could make the bacteria become pathogenic for the calves and cause the progressive and destructive inflammation of the periodontium with all the known consequences.

Döbereiner et al. (1974) described CI on recently established farms in 1969 in former virgin forest-areas in the State of Mato Grosso (Fig.l). Two early papers were found in the literature, which report a disease in calves diagnosed as "necrobacillosis", a condition that appears from the description and the figures identical to the clinical picture of CI. Giovine et al. (1943) reported its occurrence in the "Zona da Mata", State of Minas Gerais, and Lamounier \& Pereira (1945) observed the disease in the Paraíba river valley, State of São Paulo.

As seen by the authors of this review after the many years of investigation of $\mathrm{Cl}$, the disease is or was endemic and its occurrence patchy in large areas of Brazil, mainly of the central-western region of the country (Fig.2). CI apparently also occurred in Bolivia (L.R. McDowell, University of Florida, Gainesville, personal communication).

2. Disease history, clinical signs and pathological alterations of "cara inchada" in cattle (CI)

Döbereiner et al. (1974) began to investigate $\mathrm{CI}$ in zebu herds of Mato Grosso, where they collected epidemiological data, performed clinical and post-mortem examinations in the field, completed by histopathological studies in the laboratory.

In the late 1960s and in the 1970s, the cattle in Mato Grosso was raised to a great extent on recently cultivated Panicum maximum-pastures after the removal of the virgin forest. The chopped trees were burnt and grass was seeded in, often by means of small airplanes. On these recently established pastures $\mathrm{CI}$ occurred with an initial incidence of more than $50 \%$ in the calves. Adult cattle could also be affected; 70\% of Cl-diseased cows were once seen in a group of emaciated cattle in the fertile Jurigue river valley, near Rondonópolis, then famous for its high incidence of the disease. CI was at that time the most important malady of cattle in Mato Grosso; the farmers suffered severe losses in their herds and often had to change their production system 


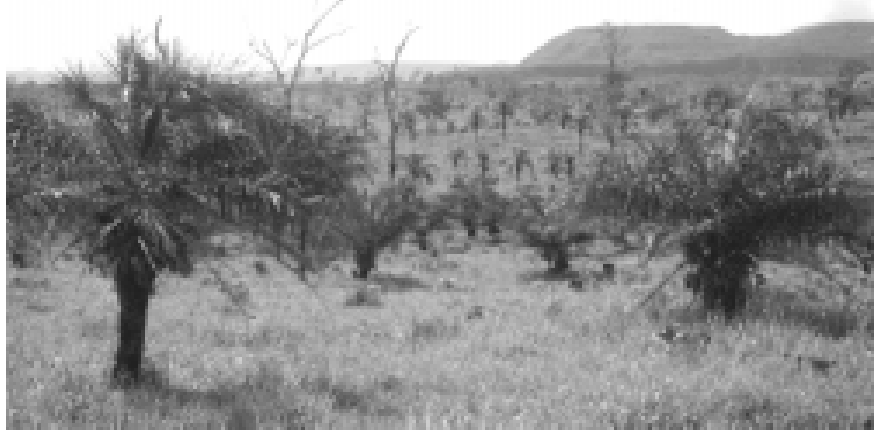

Fig. 1. A "cara inchada"-prone Panicum maximum-pasture in the fertile Jurigue river valley, Rondonópolis area, Mato Grosso, in the early 1970s. The high incidence of this disease caused great economic losses to cattle farmers after the establishment of new ranches in central-western Brazil. (From Döbereiner et al. 1974)

by only introducing yearling-cattle, into $\mathrm{Cl}$-prone areas as these were known to be more resistant than calves to the disease.

Because of the destruction of periodontal tissues, loosening and shedding of cheek teeth, $\mathrm{Cl}$ was initially labeled with the general term of "periodontal disease" (Fig. 3, 4).

The early stages of $\mathrm{Cl}$-disease consisted in the retraction of the marginal gingiva, which could already be detected in only 1 to 2-month-old calves, at a time when the interdental papilla between the erupting second and third deciduous, maxillary premolar teeth $\left(\mathrm{Pd}_{3}-\mathrm{Pd}_{4}\right.$ max.) had been formed (Fig. 5). This initial periodontal alteration of $\mathrm{Cl}$ in the young calves was always found at this site, usually affecting the animals bilaterally (Fig. 6, 7); but sometimes unilateral. A softening

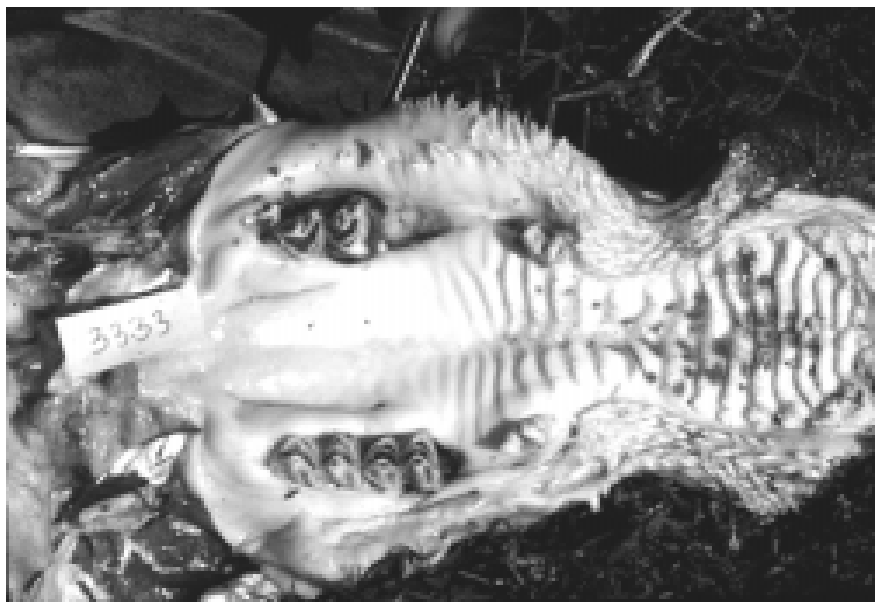

Fig. 3. Partially healed periodontal CI-lesions of the maxilla in an 18month-old bovine; the right $\mathrm{Pd}_{3}$ and $\mathrm{Pd}_{4}$ teeth and the left $\mathrm{Pd}_{3}$ were lost. (From Döbereiner et al. 1974)

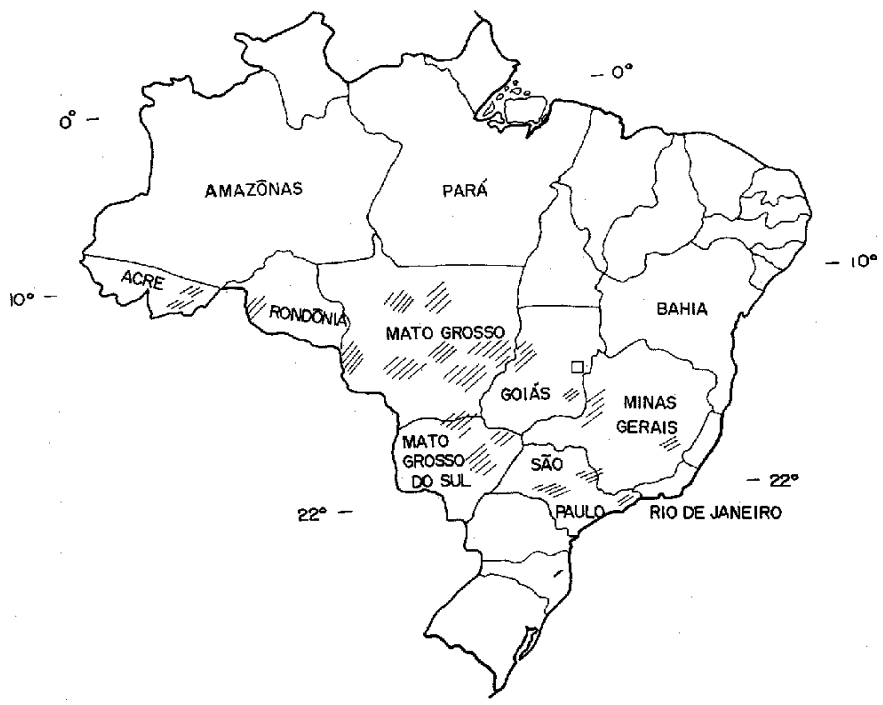

Fig. 2. The map shows the regions (/II/I) where "cara inchada" of cattle occurred in several Brazilian states. (From Döbereiner 1990)

of the tissue and a slight depression at the apex of the interdental papilla appeared initially. This developed to a periodontal pouch (Fig. 8), later filled with food particles and exhaling a typical "foetor ex ore". The lesion could also be found on the correspondent buccal papilla, but this could not be detected easily as the cheeks close tightly to the gums when the mouth is opened. In about $7 \%$ of 50 to 60 -day-old calves, some congestion around the erupting incisors and the premolars was observed. However, this alteration was observed with about the same frequency in calves on $\mathrm{Cl}$-prone and in others on $\mathrm{Cl}$-free farms, and seemed to be related to tooth eruption alone.

During the clinical examination of large numbers of calves on the many farms, less attention was paid to the lower jaw,

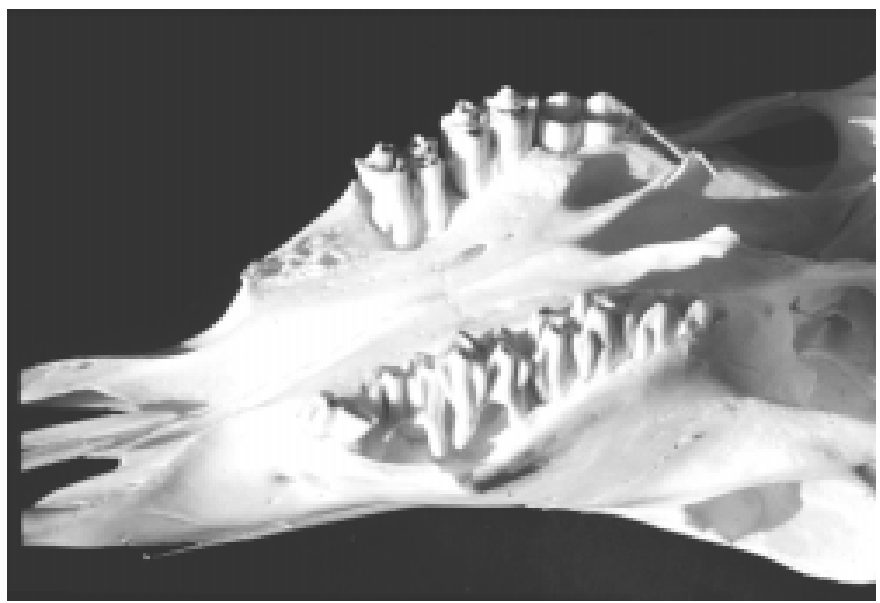

Fig. 4. The macerated cranium of a yearling steer, once affected by CI-periodontitis, shows the destruction of the alveolar bone. The lateral enlargement of the maxillae, as consequence of the ossifying periostitis, has been reduced by the healing process. (Case of the cover illustration of Pesq.Vet.Bras.17(2), 1997) 

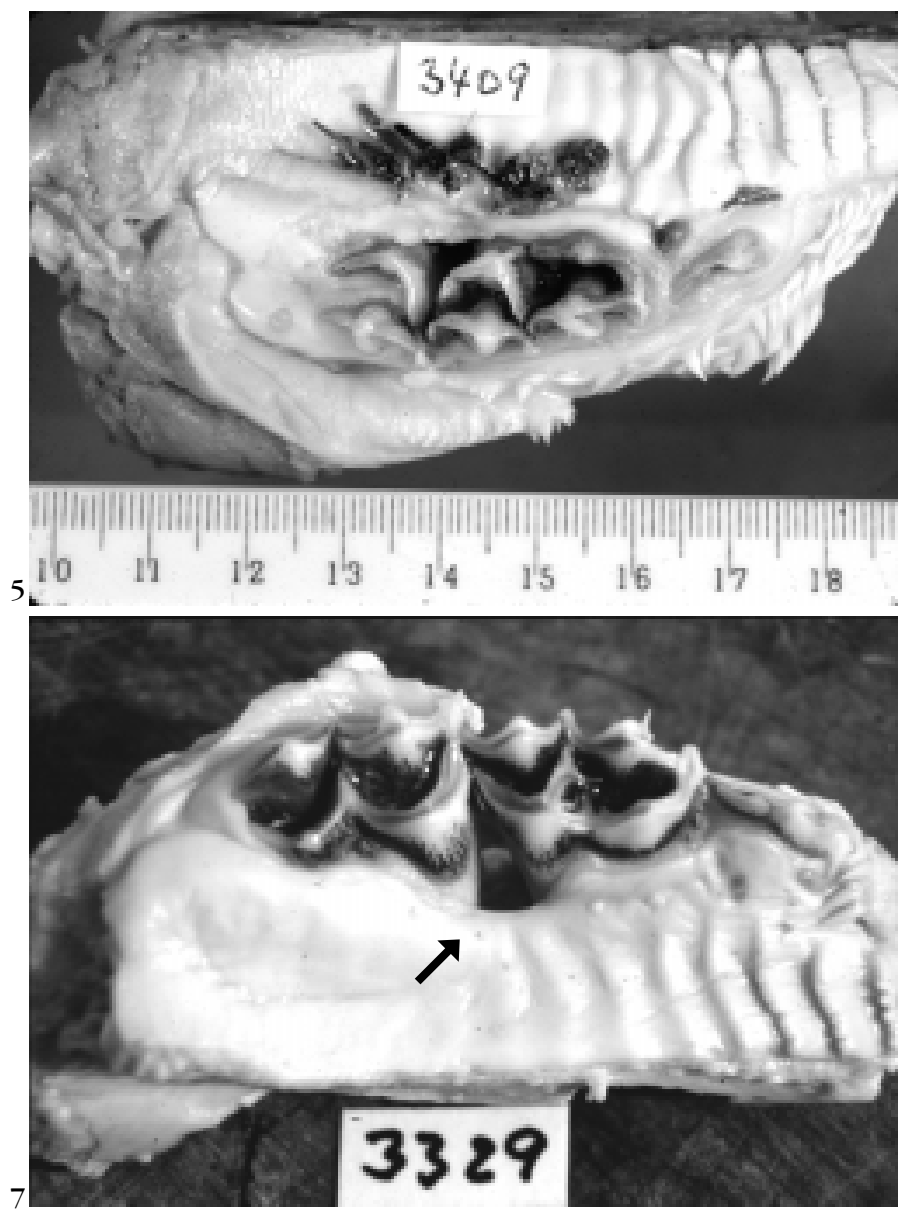

Fig. 5. A periodontal $\mathrm{Cl}$-lesion at the interdental papilla between the second and third premolar teeth $\left(\mathrm{Pd}_{3}-\mathrm{Pd}_{4}\right)$ of the upper jaw, in an 1-month-old calf. The $0.9 \mathrm{~cm}$ deep lesion was filled with the plant material shown. (From Döbereiner et al. 1974)

Fig. 7. A close-up of the formalin fixed, right dental arc of one of the cases shown in Figure 6 gives a good perception of the periodontium destroyed (arrow) by the bacteria involved in the Cl-periodontitis.

because the gingiva of the mandibula was less often affected by periodontal Cl-lesions. Therefore, the periodontal alterations on the upper jaw were always held as decisive for the clinical evaluation of the occurrence of Cl-periodontitis. In more advanced cases, the periodontal lesions could also be found between the first and second premolar teeth $\left(\mathrm{Pd}_{2}-\mathrm{Pd}_{3}\right)$ or, as in more than 5-month-old calves, between the last premolar $\left(\mathrm{Pd}_{4}\right)$ and the erupting first molar $\left(\mathrm{M}_{1}\right)$. In older and adult animals, that continued to stay on a CI-prone farm, advanced periodontal lesions involved also the molar teeth (Fig. 9, 10). If the lesions were observed only between the last premolars and the first molar teeth, one could deduce from this, that the animal was brought to the Cl-prone farm at an age when the premolars had already fully erupted but the first molars had not. This is also the case where $\mathrm{M}_{2}$ and $\mathrm{M}_{3}$ were involved; because the periodontal lesions of $\mathrm{CI}$ have
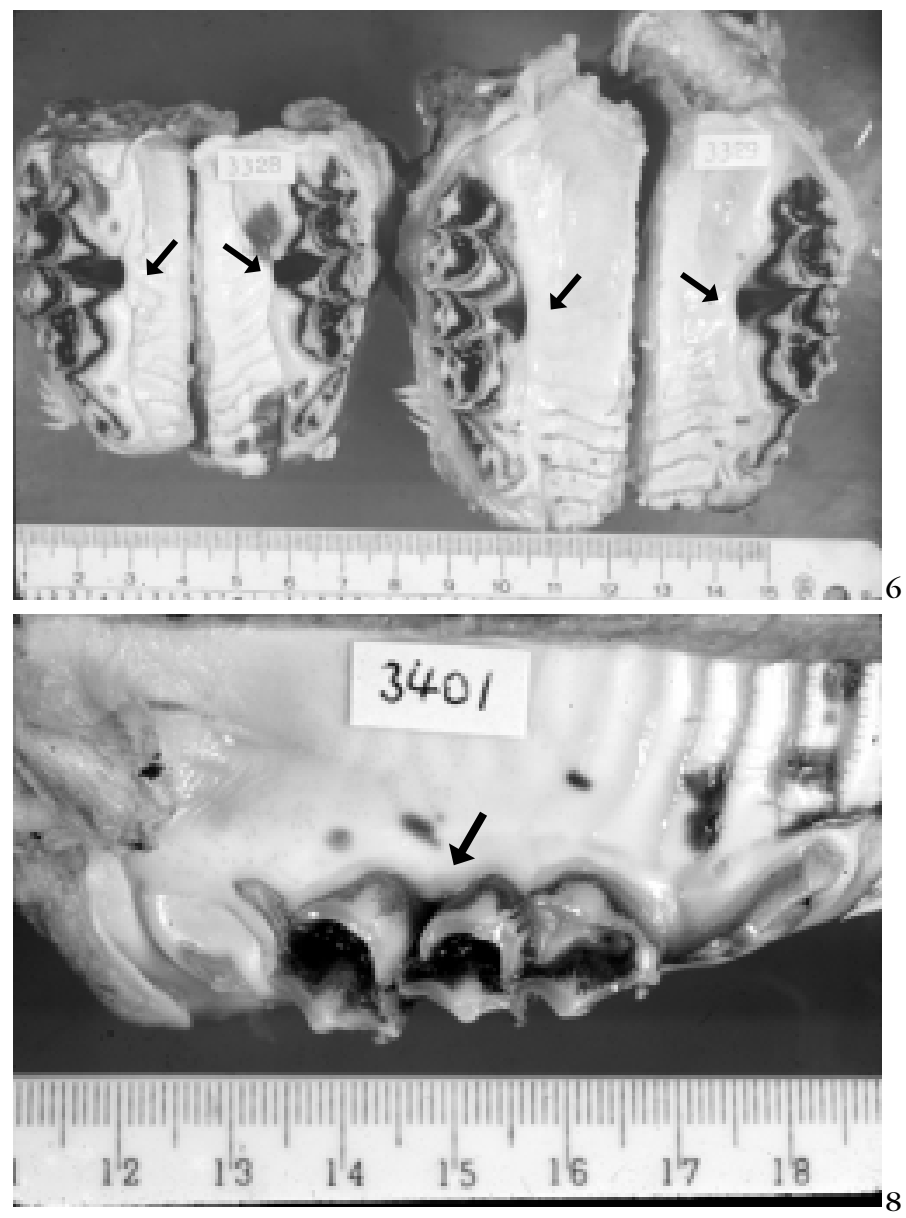

Fig. 6. Bilateral periodontal Cl-lesions in two 2-month-old calves, as they occur initially between the second and third maxillary premolars (arrows), after cleaning out vegetal debris. (From Döbereiner et al. 1974)

Fig. 8. An early periodontal Cl-lesion in a 45-day-old calf; there is a gingival retraction at the apex of the lingual interdental papilla between the left second and third maxillary teeth (arrow). (From Döbereiner et al.1974)

their onset presumably only during the stage of tooth eruption.

The bilateral or, in a few cases, only unilateral enlargement of the maxillary bones (Fig. 11,12) depended on the extension of the periodontal lesions and developed mainly in young calves. Older animals, with periodontal lesions only between the last premolar and the molar teeth, did not show the enlargement of the maxillary bones at all. With healing of the periodontal lesions, favored by shedding of the loosened premolars, the enlargement of the maxillary bone could diminish or disappear, often leaving a button-like lateral protuberance (Fig. 4, 16).

The incisor teeth were not affected by the periodontal $\mathrm{Cl}-$ alterations; but a purulent inflammatory process at the gingiva of the incisors and shedding of these teeth could occasionally be observed and was due to the presence of Cochliomyia 


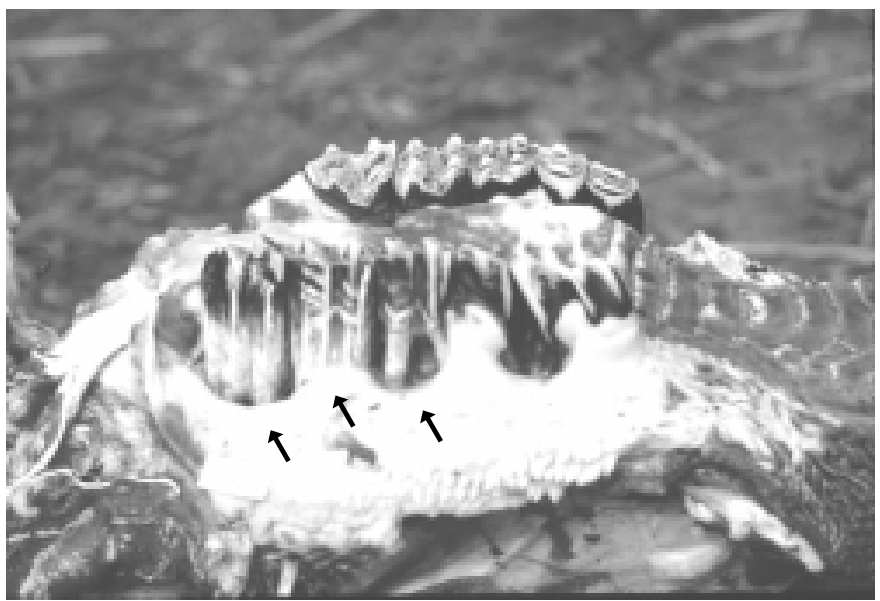

Fig. 9. The Cl-periodontitis also affects the molar periodontal tissues (arrows) when the animals continue to be kept on Cl-prone pastures. (From Döbereiner et al.1974)

hominivorax larvae originating from licking of the infested collapsed umbilical cord.

The Cl-diseased calves often had diarrhea and generally showed emaciation, rough hair coat and stunted growth (Fig. 11).

At post-mortem examination of the $\mathrm{CI}$ affected calves no alterations possibly related to the disease could be found in the inner organs, not even in the retropharyngeal lymph nodes. This points out clearly that the pathological process is localized at the periodontium.

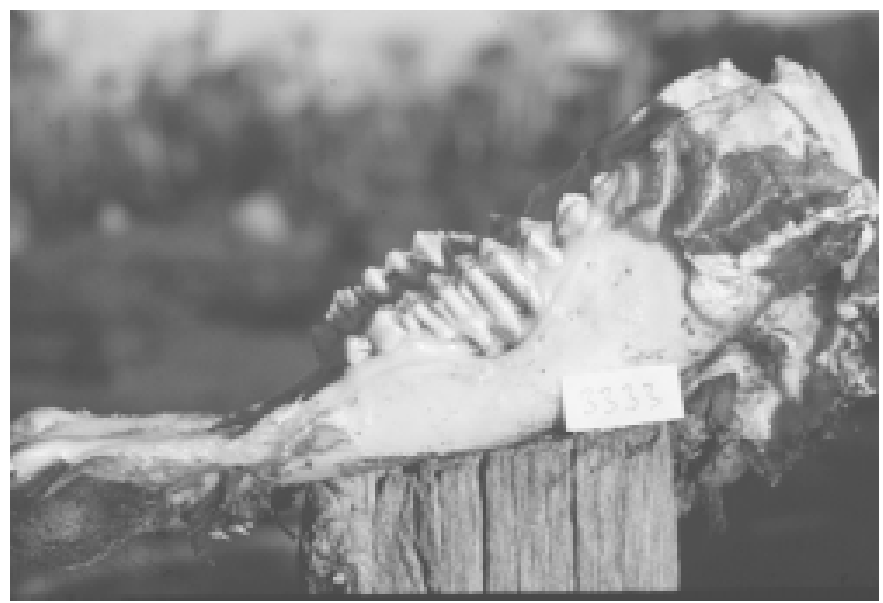

Fig.10. Periodontal CI-lesion at the level of the mandibulary $\mathrm{Pd}_{3}, \mathrm{Pd}_{4}$ and $M_{1}$ teeth in an 18-month-old ox. (From Döbereiner et al. 1974)

\section{Histopathological findings}

In the early periodontal lesions, there is ulceration of the epithelial lining and infiltration of the periodontal connective tissue mainly by neutrophilic granulocytes. The connective tissue, loosened by the inflammatory edema, borders more or less directly onto the cellular exsudate, accumulated in the periodontal pouch. There are no extensive necrotic changes in the connective tissue adjacent to the pouch (Fig. 13), which could be due to necrobacillosis, the condition postulated by Giovine et al. (1943) and Lamounier \& Pereira
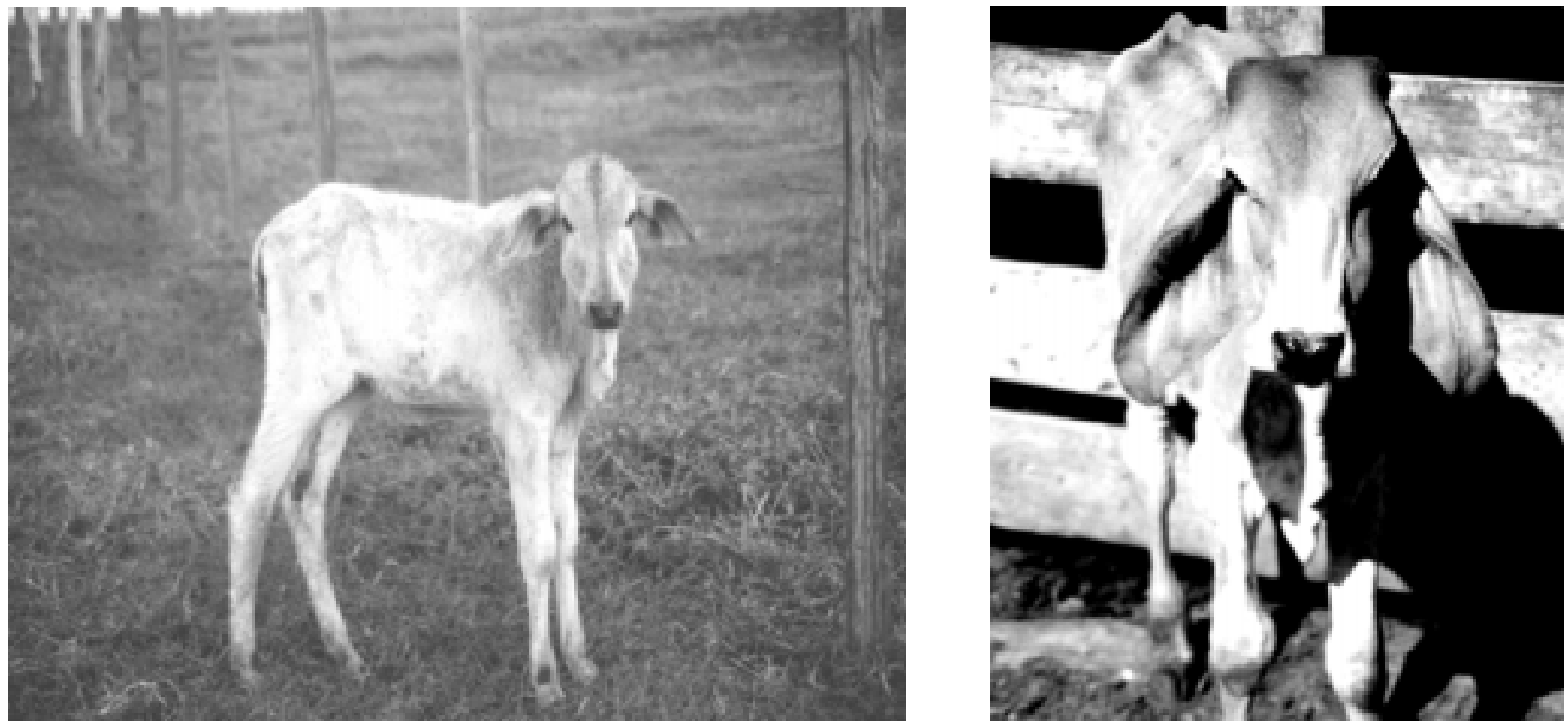

Fig.11. An extreme case of maxillary enlargement of $\mathrm{CI}$ ["enlarged face"] in a zebu calf, due to the progressive purulent periodontitis and ossifying periostitis; the animal is in bad condition, with signs of diarrhea and stunted growth. (From Pesq.Vet.Bras.13(1/2), 1993, cover illustration)

Fig.12. There may be an enlargement of only one side of the face, due to the ossifying periostitis of $\mathrm{CI}$, when the inflammatory process of the periodontium develops unilaterally. (Case of the cover illustration of Pesq.Vet.Bras.14(1), 1994) 


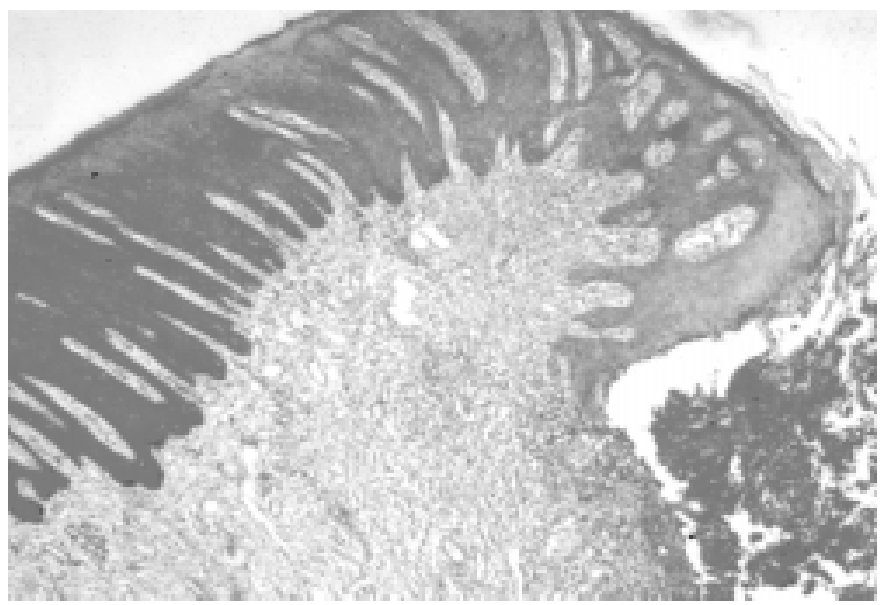

Fig.13. Ulceration in an early periodontal pouch and extensive purulent exudation of neutrophilic granulocytes, at the lingual interdental papilla between the maxillary $\mathrm{Pd}_{3}$ and $\mathrm{Pd}_{4}$ teeth of an 1-month-old Cl-diseased calf. HE, obj.4. (From Döbereiner et al. 1974)

(1945). The purulent inflammatory process reaches the alveolar bone through deepening of the periodontal pouch; destruction of the bone is characterized by osteoclastic activity and fibrous tissue proliferation. There is a lateral apposition of osteoid tissue on the maxillary bone with subsequent calcification (Fig. 14). These changes correspond to a purulent periodontitis and the picture of compensatory lateral bone formation in the alveolar region, i.e., to a chronic ossifying periostitis. (Döbereiner et al. 1974)

Histological examinations of the periodontal collagen connective tissue of $\mathrm{Cl}$-diseased calves did not reveal any primary alterations of their structure, which could cause an eventual diminished functional capacity of the periodontium (Seifert et al. 1983).

Disturbances of the mineral metabolism in the form of a secondary hyperparathyroidism have been postulated as the cause of a possible faulty development of the alveolar bone (Nunes et al. 1979, Brito 1983, Souza 1987). According to the concept of L. Krook (Cornell University, Ithaca, NY) this means that the primary cause of $\mathrm{CI}$ should be sought in general bone changes. Such disturbances would lead to resorption of the alveolar bone by fibrous osteodystrophy. In search for these possible alterations in the skeleton, they examined the scull, vertebrae and long bones of 7 to 13 -month-old cattle affected by $\mathrm{CI}$. As the ribs show the first and most distinctive alterations in generalized diseases of the skeleton, Döbereiner \& Dämmrich (1997) carried out histological and microradiographic examinations of the ribs of $17 \mathrm{CI}$-diseased 2 to 6month-old calves and of three affected animals of 7 to 10 months of age. In none of these calves could changes of the skeleton due to disturbances of the mineral metabolism be detected. This means, that no evidence of a fibrous osteodystrophy, as symptom of a secondary hyperparathyroidism in dietary Ca-deficiency and/or P-excess, was found. Disturbances of mineralization of the newly formed bone tissue, in the form of rickets or osteomalacia, due to P-deficiency, could

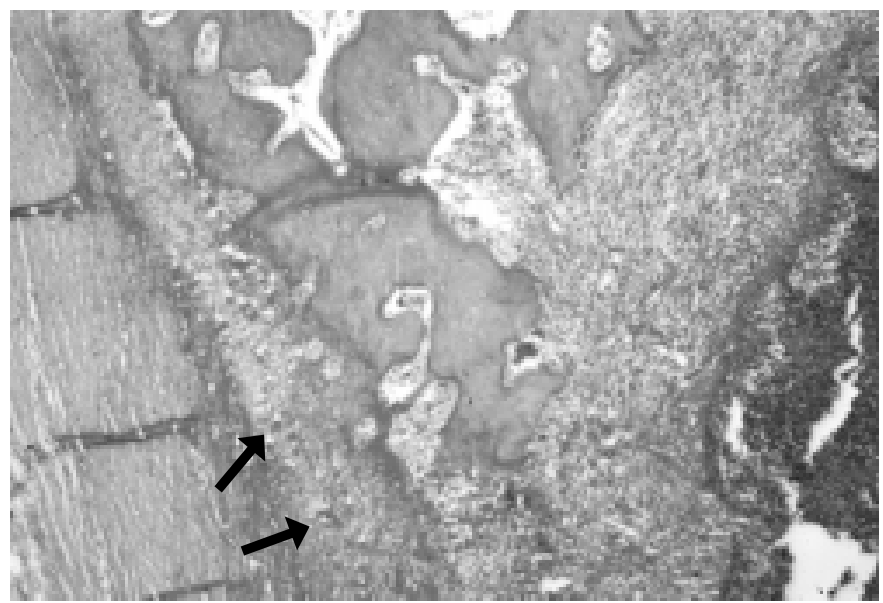

Fig.14. The purulent CI-periodontitis, at the level of the maxillary $\mathrm{Pd}_{3}$ and $\mathrm{Pd}_{4}$ teeth, led to destruction of the alveolar bone (right) and to chronic ossifying periostitis (left, arrows) in a 5-monthold calf. HE, obj.4. (From Döbereiner et al. 1974)

not be established either. Correspondingly, the parathyroid glands collected from three Cl-diseased calves did not show signs of increased secretory activity, and the parenchyma consisted exclusively of inactive dark chief cells. Therefore, the theory that disturbances of mineral metabolism favors the formation of periodontal pouches around $\mathrm{Pd}_{3}-\mathrm{Pd}_{4}$, because of a faulty development of the alveolar bone in $\mathrm{CI}$, was not supported.

In earlier investigations it was suspected that $\mathrm{CI}$ affected calves would have a reduced osteogenesis or osteopenia/ osteoporosis. Here again it appeared possible that a reduced osteogenesis could lead to the hypoplastic development of the alveolar bone and to the formation of periodontal pouches (Brito 1983, Soni 1984, Souza 1987). The study by Döbereiner \& Dämmrich (1997) of the 20 calves with CI mentioned above, showed that reduced osteogenesis was not always present. No signs of reduced osteogenesis was found in seven calves. The rest showed signs and these were more distinct in seven cases which were also accompanied by diminished chondral growth. There was a correlation between the age of the animals and the duration of the disease. Six of the seven calves with a normal formation of the skeleton were 2 to 3 months and only one was 4 months old. On the other hand, five of the six calves with a reduced osteogenesis were 4 to 5 months and only one was 3 months old, and the seven calves with a reduced osteogenesis and a diminished chondral growth were 5, 6, 7, 9 and 10 months of age. From these results it was concluded, that the reduced osteogenesis does not exist at the initial stage of $\mathrm{Cl}$, as it was seen in the 2 to 4 months old calves. This suggests that at the initial stage of the disease there is no hypoplastic development of the alveolar bone, which would favor the infection and inflammation of the periodontal tissue. Therefore, the reduced osteogenesis in the six 3 to 5 months old calves, as well as the reduced osteogenesis and diminished chondral development in the seven 5 to 10 months old calves should be interpreted as 
consequences of $\mathrm{CI}$. Reduced food intake and the impaired general stage of health, due to the infection and inflammation of the periodontium and to frequent diarrhea, appear to induce energy deficiency with catabolic metabolism. In calves that have had the disease longer, the catabolic metabolism is followed by hypoplastic osteogenesis (osteoporosis). With longer duration of the disease, the hypoplastic osteogenesis continues and is accompanied by decreased chondral growth (stunted growth). From these findings it was concluded, that in the pathogenesis of $\mathrm{CI}$ there is no faulty development of the alveolar bone; so it could not play a role as a determinant factor in the development of the inflammatory process at the marginal gingiva, which finally results in the pathological picture of CI (Döbereiner et al. 1974, Döbereiner 1990, Döbereiner \& Dämmrich 1990).

Silva et al. (1997) studied the livers of 94 crossed zebu cattle affected with $\mathrm{Cl}$, and found in $52.2 \%$ of them granulomatous lesions which contained "foam cells" in the periacinar region. They interpreted these alterations as a response to a toxin capable of inducing hepatic dysfunction of importance for the vitamin $\mathrm{D}$ and parathormone metabolism, with the view to support the hypothesis of the nutritional etiology for CI (Nunes 1996). Driemeier et al. $(1998,1999)$ examined 55 liver samples of cattle kept on pastures of different grass species and did not find such liver alterations in 40 samples collected from 1970 to 1975 . But they did find them in the other 10 animals, exactly those which had grazed on Brachiaria decumbens pastures from 1976 on. This was the year when this grass species was introduced into Brazil from Australia. They concluded that the occurrence of foamy macrophages ("foam cells") in the liver is related to the consumption of Brachiaria spp.

4. There is no scientific evidence of a mineral involvement in the etiology of $\mathrm{CI}$

Ever since the occurrence of the great outbreaks of $\mathrm{CI}$, that followed the occupation by cattle farmers of large formerly virgin forest- and "Cerrado"(tree-savanna)-areas of central-western Brazil in the 1960s and 1970s, Cl was generally considered by veterinarians and researchers as a nutritional disease due to mineral deficiency or imbalance. Calcium/ phosphorus and also copper/molybdenum were blamed.

Döbereiner's 1990 review of published experimental results, together with the analytical data of Moraes et al. (1994) and some other non-experimental evidence, led to the conclusion that there is no valid support for a mineral etiology of $\mathrm{Cl}$, because no mineral supplement alone was able to cure animals with periodontal lesions or to prevent the onset and development of the disease in healthy calves. Rosa \& Döbereiner (1994) emphasized that the drastic reduction of Cl-incidence since the 1980s was not related to improvements in mineral supplementation programs, because diseases associated with mineral deficiencies or imbalances are still a common occurrence in former $\mathrm{Cl}$-areas. Non-official data indicate that at present less than $30 \%$ of the cattle in Brazil receive an adequate (quality and quantity) mineral supplementation. Moreover, pastures become nutritionally poorer in mineral elements with time, and so if the cause of $\mathrm{Cl}$ was a mineral deficiency, the incidence of the disease would be increasing and not decreasing to the point of complete disappearance. These conclusions (Rosa \& Döbereiner 1994) are also supported by a later study (Döbereiner \& Dämmrich 1997), on secondary bone changes occurring in Cl showing that there is no evidence for a relationship of $\mathrm{Cl}$ with mineral deficiency or imbalance.

Sousa et al. (1986) studied the effect of mineral supplementation on the incidence of $\mathrm{Cl}$ by an experiment of 387 days with 170 calves, distributed into 10 treatments, each with $15 \mathrm{Cl}$-diseased animals and 2 healthy controls, which were maintained on Brachiaria decumbens-pastures on a $\mathrm{Cl}$ prone farm in Mato Grosso do Sul (Bracinho, county of Bandeirantes). The animals were supplemented with different mineral mixtures rich in macro and microelements. From clinical examinations of the gingiva it was concluded that copper supplementation had some favorable effect on the recovery of animals from $\mathrm{Cl}$-periodontitis.

Two other field experiments were conducted on Cl-prone farms, in the late 1970s, by J.C. Sousa (Unpublished data), working on animal nutrition at the National Center for Beef Cattle Research (Embrapa-CNPGC) in Campo Grande, Mato Grosso do Sul. The aim was to evaluate a possible efficacy of mineral supplements provided to the cows from the last third of pregnancy on, in order to prevent the onset and development of $\mathrm{Cl}$ in their calves from birth to weaning at 8 months of age. In the first experiment, on farm Itaverá, county of Campo Grande, the treatments were: 1 ) sodium chloride only, 2) special mineral supplement formulated according to NRC requirements, and 3) routine mineral supplement already in use on the farm. The last examination of the calves at weaning revealed a $67 \%$ incidence of $\mathrm{Cl}$ periodontal lesions in calves from treatment 1 , a $62 \%$ incidence in treatment 2 , and $48 \%$ in treatment 3. In the second experiment, on farm Campo Bom, county of Cassilândia, with a lower incidence of $\mathrm{CI}$, the treatments were: 1 ) a routine mineral supplement in use by the farm, 2) a special mineral supplement formulated according to NRC requirements, and 3) a "commercial mineral mixture" claimed to be able to control CI. Examination of the calves at weaning indicated a $26 \%$ incidence of $\mathrm{Cl}$ in animals from treatment 1 , a $27.6 \%$ incidence in treatment 2 , and only $8.5 \%$ in treatment 3 . The results of these two experiments showed that the commercial special supplement (treatment 3 , second experiment) was the only product with some specific action against the incidence of Cl-periodontitis. (I.V. Rosa, personal communication)

Since there was nothing unusual in the mineral composition of the "commercial mineral mixture" used in the above mentioned experiment on farm Campo Bom, it was suspected that some additive with antibiotic action might have been present in the mixture. Two samples of this mineral supplement, acquired at different localities in Mato Grosso do Sul, were tested "in vitro" for their possible bacteriostatic effect. One of the two samples inhibited bacterial growth on culture medium, whilst the other did not show any bacteriostatic action (H.Blobel, unpublished data). It was then suspected that some sort of antibiotic was added to those batches of this product intended for use in regions with $\mathrm{Cl}$. 
This might be capable of interfering with the growth of microorganisms responsible for the periodontal lesions of $\mathrm{Cl}$, helping to prevent the disease in healthy calves and to cure the lesions in animals already affected.

The inconclusive results of those field trials still contribute to recommendations for supplementation based on the dubious belief that $\mathrm{CI}$ is due to mineral deficiency or imbalance.

In a geochemical investigation, soil samples were collected from $12 \mathrm{Cl}$-prone and $8 \mathrm{Cl}$-free farms in the states of Mato Grosso do Sul, Mato Grosso and Acre, in the mid 1970s, and analyzed spectrographically. Although semi-quantitative, this allowed an evaluation of possible dissimilarities between the mineral contents of the soils of the two groups of farms (A.C.J. Castro, Federal University of Rio de Janeiro, unpublished data). These analytical results failed to show any significant differences that could explain the incidence of $\mathrm{Cl}$ on the $\mathrm{Cl}$ prone farms.

\section{Bacterial isolations from periodontal Cl-lesions}

From the periodontal lesions of $\mathrm{CI}$ affected calves blackpigmented non-saccharolytic Bacteroides melaninogenicus and Actinomyces (Corynebacterium) pyogenes could be isolated, always and in large numbers. Smaller numbers of Bacteroides bivius, Fusobacterium nucleatum and Actinomyces israelii were also found (Blobel et al. 1984, 1987). The systemic classification of the Gram-negative, anaerobic, non-sporulating bacteria capable to form black-pigmented colonies in culture medium containing hemine and vitamin $K$, and of nonpigmented, saccharolytic and non-saccharolytic bacteria, is complex. These bacteria, previously known as Bacteroides spp, mainly $B$. melaninogenicus, could possibly be regrouped within the genera Porphyromonas, Prevotella and Bacteroides (Shah \& Collins 1988, 1989, 1990).

The search for tissue destroying enzymes and an endotoxic effect due to these bacteria, showed that black-pigmented cultures of B.melaninogenicus, F.nucleatum and A.pyogenes produce collagenase, desoxyribonuclease, chondroitinsulfatase, fibrinolysin, gelatinase, hyaluronidase, lipase and protease (Dutra et al. 1986). There was also shown a "trypsinlike" proteolytic effect in cultures of black-pigmented nonsaccharolytic B.melaninogenicus with a similar profile of Bacteroides gingivalis, isolated from humans. It also produce large quantities of collagenases. The biological activity of lipopolysaccharides extracted from black-pigmented nonsaccharolytic Bacteroides spp and F. nucleatum was demonstrated through their necrotic effect in the cutaneous Shwartzman-reaction of the rabbit.

These results pointed to the etiological role of the isolated bacteria, mainly Bacteroides melaninogenicus together with Actinomyces pyogenes, and their enzymes and endotoxins, in the development of the periodontal lesions of $\mathrm{CI}$.

The typical, putrid odor, which arose with the cultivation of black-pigmented B.melaninogenicus in the laboratory, was very similar to the odor perceived at clinical examination of the oral cavity of Cl-periodontitis affected cattle. This typical odor ("foetor ex ore") was always considered a sign that one dealt with an actively progressing periodontal lesion (Döbereiner 1990).

6. Characterization of anaerobic bacteria isolated from periodontal CI-lesions

Botteon et al. (1993) isolated 4 groups of microorganisms, in order to try to identify the anaerobic bacteria involved in the periodontal CI-lesions. From 120 isolated samples, 52 were selected to establish the biochemical profile using the API 20 A-system. Twenty five pertained to Group 1 (black-pigmented colonies with filamentous forms), 13 to Group 2 (brownpigmented colonies), 8 to Group 3 (blue-pigmented colonies), and 6 to Group 4 (yellow-pigmented colonies). The microorganisms of Group 1 and 2 were of the genus Bacteroides. From these 38 black- or brown-pigmented cultures, 15 were non-fermentative and presented a profile similar to nonsaccharolytic Bacteroides spp, whilst the other 23 did not pertain to any of described species. These cultures had different degrees of fermentation or hydrolysis of substrates, some with common, others only with individual characteristics, and were consequently classified as black- or brownpigmented saccharolytic Bacteroides spp. The cultures of Group 3 frequently showed the capacity to ferment various sugars, and only one culture was indol-negative. With this biochemical profile, the bacteria were defined as Bacteroides spp. The cultures of Group 4 were identified as Fusobacterium nucleatum, although the morphologic aspect of the colonies differed from that described in the literature. Additionally, the other 68 bacterial cultures belonging to the 4 isolated groups were selected for the study of their growth capacity in culture medium BCA and formation of a fluorescent pigment. A total of 120 cultures were examined. The cultures of Groups 3 and 4 were non-fluorescent, while 24 of the black- and 9 of the brown-pigmented cultures tested, were positive for fluorescence.

The results of this study showed the presence of specific groups of non-sporulated, Gram-negative bacteria in the periodontal Cl-lesions, with a predominance of black- or brown-pigmented saccharolytic Bacteroides spp, as well as the presence of non-pigmented fermentative Bacteroides spp and of Fusobacterium nucleatum.

7. Cattle affected by Cl-periodontitis recovered after their transfer to a $\mathrm{Cl}$-free area

Information was obtained from cattle breeders, that animals recovered from $\mathrm{CI}$ after they were transferred from Cl-prone farms to a region where the disease had never occurred. To get experimental proof of this, 33 bovines with 8 months to 3 years of age, severely affected by the disease, were taken from Cl-positive farms in the Rondonópolis area to a Cl-free farm situated in the virgin "Cerrado" (tree-savanna) of Itiquira, Mato Grosso (Döbereiner et al. 1975). Bi-monthly clinical examinations of 17 cattle, which survived in spite of the initial cachexia, without any special treatment besides the administration of a vermicide, revealed recovery from the periodontitis within 5-6 months. Periodontal lesions already showed healing from 2 months on with a reduction 


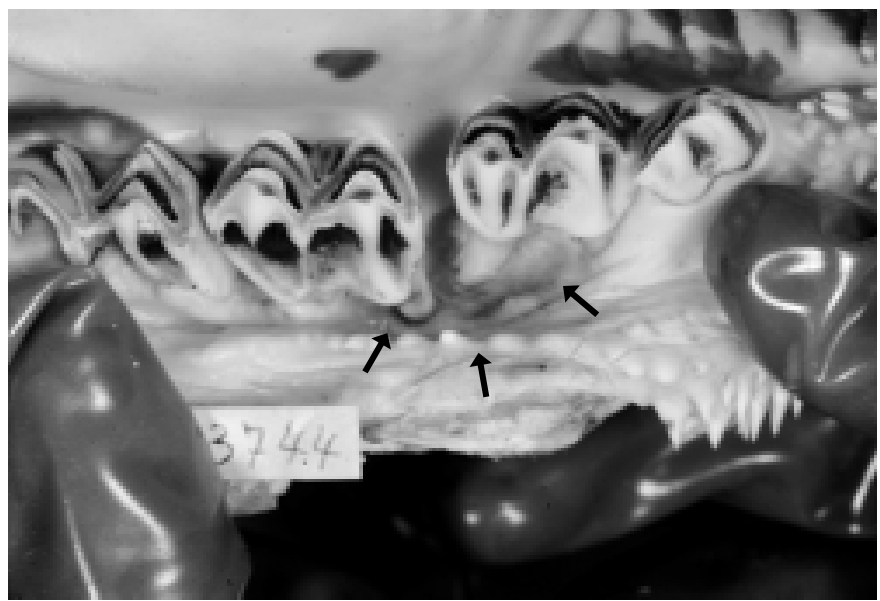

Fig.15. Superficially healed periodontal CI-lesions at the level of the left maxillary $\mathrm{Pd}_{3}$ and $\mathrm{Pd}_{4}$ teeth (arrows), in a 9-month-old calf which had been transferred 5 months previously from a Cl-prone area to the CI-free virgin "cerrado". (From Döbereiner et al. 1975)

of the "foetor ex ore" and in the enlargement of the maxillary bone, as well as an improvement of the nutritional state of all animals. The previously loosened deciduous premolar teeth in four recovered calves, sacrificed and necropsied for a more thorough examination, had tightened again, and the purulent periodontal lesions had healed; but the gingival tissues retracted to a more apical level and the defects caused by bone degradation remained unchanged (Fig. 15). Similar observations were made in 1987, when four 9 months old Cl-

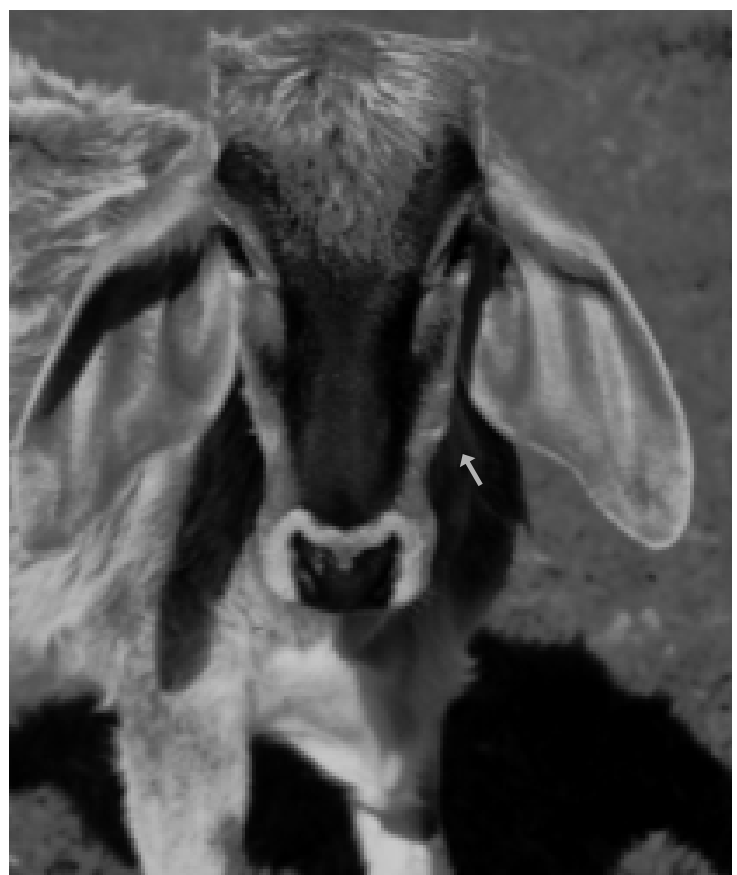

diseased calves were transferred from a Cl-prone farm in the State of São Paulo (Recreio, mun.Campos Novos Paulista) to the Institute in the Rio de Janeiro area (Dutra et al. 1999). The periodontal lesions healed within several months without any special treatment, as it had occurred in the natural "Cerrado" of Itiquira, Mato Grosso, and the enlargement of the maxillary bones disappeared (Fig. 16, 17). These experimental results suggested that $\mathrm{Cl}$ is a disease in which a determinant dietary factor, apparently other than mineral elements, could be present in the pasture of $\mathrm{Cl}$-prone areas.

8. Panicum maximum-pastures free of weeds appeared to contain a determinant factor for the development of $\mathrm{Cl}$ periodontitis

In order to exclude the existence of plant species other than grass that could contain a periodontitis-factor, experiments were performed on two Cl-prone farms (Paulicéia and Santa Escolástica, Rondonópolis area, MT), where Panicum maximum-pastures were cleaned from all weeds. On the first farm, six 4 to 5 months old by $\mathrm{Cl}$ affected calves were kept, together with their mothers, on a "clean" pasture during 5 months. On the other farm, about 1 year old Cl-diseased calves were maintained on such a pasture for 7 months. Repeated clinical examinations of the calves revealed that the periodontal lesions had persisted or worsened till the end of the experiment. At the same time, 67 zebu cows together with their 3 week-old calves were kept on the "clean" pasture of the first farm (Paulicéia). The calves were repeatedly submitted to clinical examination of the maxillary gingiva till the age of 9 months, by when $52.2 \%$ had developed Cl-periodontitis. This

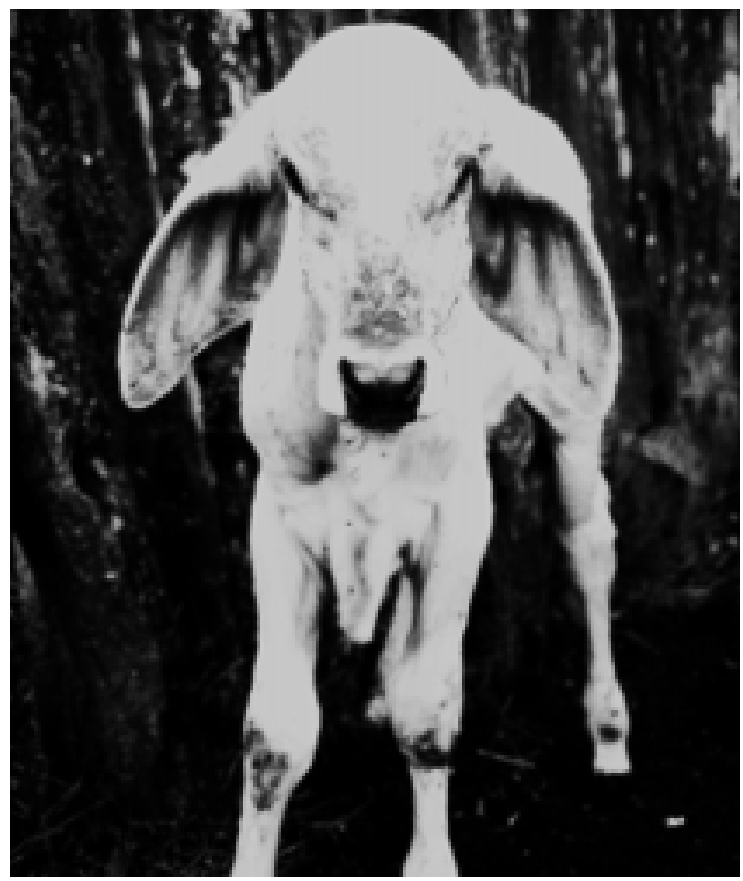

Fig.16. Almost complete disappearance of the previous bilateral enlargement of the upper jaw of a 10-month-old Indubrasil calf, that had been transferred from a Cl-prone farm in the State of São Paulo to the Cl-free State of Rio de Janeiro 8 months previously. At its left side remained only a small button-like protuberance (arrow), typical for cases of cured Cl-periodontitis (From Döbereiner 1990)

Fig.17. The calf of Figure 16, affected by CI-periodontitis and with enlargement of the maxillary bones, at an age of about 45 days, when it was still on the Cl-prone farm. (From Döbereiner 1990) 
suggested that the pasture-grass could contain the dietary factor causing Cl-periodontitis. (Döbereiner et al. 1976)

9. Bacteriological monitorship of the regression and cure of Cl-periodontitis

It had been observed in a previous experiment (Döbereiner et al. 1975), that Cl-diseased animals recovered within a few months without any special treatment when transferred from the Cl-prone Jurigue river valley to a virgin "cerrado"-area in Mato Grosso. So in 1987, Cl-diseased calves that showed enlargement of the maxillary bones to different degrees, were transferred from an endemic area in the state of São Paulo to the Cl-free state of Rio de Janeiro (Dutra et al. 2000). The objective was to monitor the expected regression and healing of the periodontal Cl-lesions with bacteriological examinations. Thirteen transferred calves were examined clinically at the beginning of the experiment and at intervals. Material for bacteriological examination was collected regularly by curettage from the periodontal pouches. After dilution in neutralized pre-reduced solution, the samples were cultured on CDC-blood agar anaerobically. In the samples taken from the actively progressing periodontal lesions immediately after the transference of the calves, an intensive growth of black and brown-pigmented colonies was observed. These represented $71.3 \%$ of the cultures. These strictly anaerobic, Gramnegative, non-sporulating bacteria, predominating in the actively progressing periodontal lesions, were identified as being Bacteroides spp, because they were saccharolytic or nonsaccharolytic when tested with the API 20 A-system. When the animals showed a clinical improvement, characterized mainly by disappearance of the "foetor ex ore", the number of black-pigmented colonies diminished greatly in the material collected from the periodontal pouches. These bacteria were reduced more rapidly from shallow than from more severe lesions with deeper pouches. In general, there was a correlation between the number of these bacteria and the clinical recovery with regression of the periodontal lesions. The material collected from the periodontal alterations of the calves considered to have recovered clinically, resulted in the culture of $1.7 \%$ of black-pigmented colonies. A similar number of black-pigmented colonies was found from materials collected from the marginal gingiva of calves born and raised in $\mathrm{Cl}$-free areas. From this, it could be deduced that this group of microorganisms often takes part of the gingival microflora, and that the occurrence of Cl-periodontitis is associated with an increase in their predominance compared to anaerobic bacteria with non black-pigmented colonies. In all actively progressing periodontal $\mathrm{Cl}$-lesions this group of bacteria forming black-pigmented colonies was predominant. This provides strong evidence that $\mathrm{Cl}$ periodontitis does not develop without their colonization and increase in number.

10. Confinement of calves affected by $\mathrm{CI}$ led to healing of the periodontal lesions

In order to confirm the healing effect of the transference of by $\mathrm{CI}$ affected cattle to a Cl-free virgin "cerrado"-area, on two farms in Mato Grosso (Santa Escolástica and Paulicéia, in the Rondonópolis area) Cl-diseased calves were confined and maintained with a ration consisting of corn, cottonseed meal and sugar cane molasses brought into the farm (Rosa et al. 1976). These animals also received a mineral mixture and vitamin A. On one farm six 4-5 months old weaned calves were used, and on the second farm ten yearlings were confined. After 5-6 months of isolation from the Cl-prone pastures, the periodontal lesions, with exception of one small defect in an exceedingly severe case, had healed. After only 4 months, healing could clearly be observed and became evident trough the disappearance of the typical "foetor ex ore". Six and eight control animals in the two experiments that had been left during this time on Cl-prone pastures, showed no healing of their periodontal lesions. Nutrition was not considered important as the $\mathrm{Cl}$-diseased cattle recovered after being transferred to a farm in the virgin "Cerrado" with very poor soils (Döbereiner et al. 1975). In another trial, cattle affected by the disease on a CI-prone farm (Santa Isabel, county of Xavantina, MT) did not recover when confined and supplemented with rich forage grown on recently cultivated fertile soil (J. Döbereiner, personal observation). These two cases suggest that the nutritional quality of the food has little influence on the recovery of calves from $\mathrm{Cl}$-periodontitis. $\underline{\mathrm{A}}$ transient factor present in the pasture or forage is a more probable cause. After its disappearance, the bacteria responsible for the periodontitis would loose their pathogenicity, so that the periodontal lesions could heal without any other special treatment.

11. Avoidance of burning the cut forest did not help to recover $\mathrm{Cl}$-calves from the disease

At the end of the 1960s and in the 1970s, Cl was observed on farms in Mato Grosso and Goiás where virgin soils had been cultivated for pasture formation after eliminating the natural forest by burning the cut trees. In order to investigate a possible influence of burning the wood and the subsequent deposition of large amounts of ash on the soil for the development of $\mathrm{Cl}$ periodontitis, an experiment was made on a Cl-prone farm (Santa Escolástica, in the Rondonópolis area, MT) (Döbereiner et al. 1978). Eight Cl-affected young calves and their mothers were maintained on a recently cultivated Panicum maximum-pasture, in which the cut forest had not been burnt. Eight other Cl-calves with their mothers were kept as controls on a newly cultivated adjacent $P$. maximum-pasture, where the cut forest was burnt. Repeated clinical examinations of the calves revealed that after 5 months the periodontal lesions in both groups were persistent or had worsened. This suggested, that the practice of burning the chopped trees was not a factor "sine qua non" for the development of CI-periodontitis. Nevertheless, the ashes elevate the $\mathrm{pH}$ of the soil and could be expected to modify the soil microflora. In this context, it should be mentioned that in $\mathrm{Cl}$ prone areas, the occurrence of the disease was apparently avoided when the land, developed after removing forest, was used for agricultural crops for some years before being transformed into cattle pasture (J. Döbereiner, personal observations). This shows that the determinant factor is transient. 
12. The milk of the mother-cows, kept on CI-prone pastures, seemed to contain the supposed determinant factor for development of the periodontitis in their calves

In order to verify the possible excretion with the milk of the supposed determinant factor for development of the $\mathrm{Cl}$ periodontitis in the suckling calf, an experiment with five 3 to 4 months old by $\mathrm{Cl}$-affected calves was made. The animals were confined to a "corral" on the Cl-prone farm Paulicéia, Rondonópolis area (Döbereiner et al. 1987), to the same "corral" where a year before four young Cl-calves fed a ration from outside the farm, had recovered from the $\mathrm{Cl}$-periodontitis after about 5 months (Rosa et al. 1976). Their mothers, kept on a Cl-prone pasture, were brought in to give milk to the calves twice a day. These also received roughage in form of fresh grass provided daily from a natural, undisturbed "Cerrado"(savanna)-area within the same farm. Repeated clinical examination showed a persistence and aggravation of the periodontal lesions leading to poor condition of the calves after 4 and a half months (Fig. 18). This experimental result indicated that the supposed determinant factor for develop-ment of the infectious periodontitis is also present in the milk of the mother-cows grazing on a Cl-prone pasture. This explains how calves affected by the Cl-periodontitis, at the early age of 1 to 2 months when fed mostly on milk (Döbereiner et al. 1974).

13. Occurrence of $\mathrm{Cl}$ in the "Cerrado" (tree-savanna) after its first cultivation for pasture formation

After the first cultivation of virgin "Cerrado"-soils and establishment of the pasture grass Brachiaria decumbens, during the late 1970s, $\mathrm{Cl}$ began to appear for the first time also in these former natural tree-savanna areas. As in former

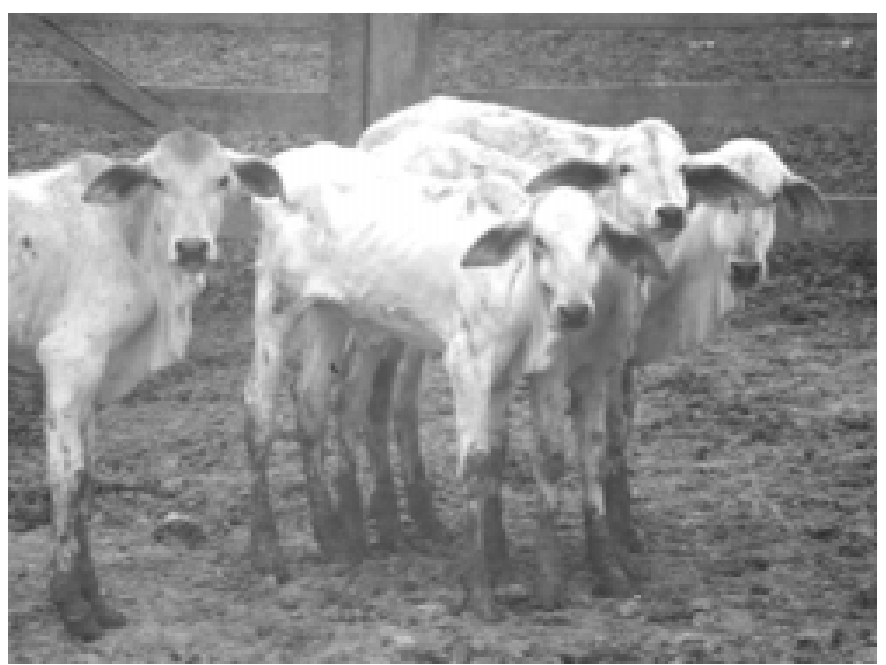

Fig.18. The periodontal CI-lesions and the enlargement of the maxillae of confined calves, which received grass from a virgin Cl-free "Cerrado"-area, but continued to be fed on milk from their mothers kept on a Cl-prone pasture, persisted or worsened during the almost 5 months experiment; this pointed to the passage of a determinant factor most likely contained in the pasture-grass through the milk. (From Döbereiner et al. 1987) virgin high forest-areas cultivated for the first time for pasture growth, the incidence of $\mathrm{Cl}$ reached in the recently cultivated "Cerrado" more than $60 \%$ the calves (J. Döbereiner, unpublished data). This again indicated, that the recent cultivation of virgin soils for cattle pasture was important for the occurrence of $\mathrm{Cl}$, and that the supposed determinant factor for the development of the periodontitis is probably present in the pasturegrass.

14. Outbreak of $\mathrm{Cl}$ in the "High Pantanal" of Mato Grosso after the first cultivation of a virgin area with Panicum maximum-grass

In the temporary flooded, virgin low lands of the Pantanal region, $\mathrm{Cl}$ is never observed in its large cattle population. However, in the mid 1970s, the disease occurred in a bordering, somewhat higher, non-temporary flooded area of the Pantanal known as the "High Pantanal" (County of Santo Antonio de Leverger), soon after virgin forest was eliminated and Panicum maximum-pasture established (J. Döbereiner, unpublished observation). Once more a recently disturbed virgin soil and a newly established pasture are determinant factors for the development of Cl-periodontitis, whilst cattle kept in virgin areas of undisturbed soil remain free of the disease.

15. Renewed outbreaks of $\mathrm{Cl}$ on farms, when long-standing undisturbed soils were freshly cultivated for pasture improvement or forage production

Renewed outbreaks of $\mathrm{CI}$ were observed on two farms in the state of São Paulo, on which $\mathrm{Cl}$ had last occurred about 15 years ago (Dutra et al. 1993). On the first farm (Canaã, county of Barretos), all the old-standing Brachiaria spppastures had been newly ploughed, limed and fertilized, leaving no "old" pasture for the cattle. On the second farm (Santa Fé, county of São Carlos), an area, with undisturbed soils for many years, had been prepared in the same way and planted with sugar cane for supplementation of the cattle during the dry season. On the farm in Barretos, 41 of 79 calves (5l.9\%) were affected by $\mathrm{CI}$, and $3(3.6 \%)$ of them died of the disease. On the farm in São Carlos, 245 of 398 calves (61.5\%) were affected by $\mathrm{CI}, 11 \%$ of these animals showed enlargement of the maxillary bones, and 195 (79.6\%) of the animals with Cl-periodontitis died.

A high incidence of $\mathrm{CI}$ (25 to $100 \%$ of the calves) was observed on minor dairy farms with European cattle crossed with Zebu, in the region of São Simão, State of São Paulo, in the late 1980s. The disease apparently had once occurred there after clearing the virgin forest for the establishment of the farm many years ago. Newly affected cattle on these farms were grazing on "old", long-standing pastures, but were fed to a great extent, mainly during the dry season, with forage grown on small, recently cultivated areas. On a larger farm (Andorinha) in the same region, $\mathrm{Cl}$ also occurred at this time in a zebu herd maintained on recently cultivated pastures after clearing of the natural "cerrado"-vegetation. (J. Döbereiner \& I.S. Dutra, unpublished data)

All these observations pointed once more to the existence of a determinant factor for the infectious Cl-periodontitis in 
the forage, grown not only on recently cultivated virgin soils but also on former Cl-prone soils, undisturbed for many years and then newly cultivated and planted with pasture grasses.

16. Inefficiency of parenteral administration of antibiotics for the treatment of $\mathrm{Cl}$-periodontitis

With the aim to test the efficiency of parenteral administration of antibiotics for the treatment of $\mathrm{Cl}$-calves, experiments were undertaken on two farms with over a $50 \%$ incidence of the disease. In the first trial 39 calves of 8 to 9 months were kept on Cl-positive Panicum maximum-pastures in Mato Grosso for 170 days (Paulicéia, county of Rondonópolis). In the second trial 64 calves of 3 to 4 months were kept on Cl-positive Brachiaria decumbens-pastures on a "Cerrado"-soil (Burity, county of Jaraguari), in Mato Grosso do Sul, until weaned at 8 to 9 months. The treatments consisted of intramuscular injections of two antibiotic preparations, which showed a major "in vitro"-effect against the bacteria isolated from the periodontal Cl-lesions. These products (Tardomycel $=$ penicillin $\mathrm{G}+$ streptomycin $0.8 \mathrm{ml} / 10 \mathrm{~kg}$, and $\mathrm{TM} / \mathrm{LA}=$ tetracyclin $1.0 \mathrm{ml} / \mathrm{kg}$, both of prolonged action) were administered in three intramuscular injections at 5 days intervals, to guarantee a strong antibiotic effect in the animal during at least a fortnight. Repeated clinical examinations of the animals did not show any benefits of this parenteral antibiotic treatment for the healing of periodontal Cl-lesions. (Rosa et al. 1985)

17. The effect of antibiotics given as additives in mineral mixtures to prevent $\mathrm{Cl}$-periodontitis

To determine the effects of the antibiotic spiramycin in the prophylaxis of $\mathrm{Cl}$, experiments were conducted on two farms with high prevalence of the disease in the previous years (Döbereiner et al. 1990). This antibiotic was chosen because it is used in odontology as its concentration in the saliva is high. The spiramycin was added to a mineral mixture freely consumed by the cattle in salt licks on the pasture. On the first farm in Mato Grosso do Sul (Burity, county of Jaraguari), 130 cows with their newborn calves were divided in two treatment groups: 1) mineral supplementation in troughs on the pasture, with the addition of $50 \mathrm{~g}$ spiramycin per $50 \mathrm{~kg}$ of the mineral mixture, and 2) the same mineral mix without the antibiotic. On the second farm in the State of São Paulo (Recreio, county of Campos Novos Paulista), 168 cows and their calves received a mineral supplement with the addition of $25 \mathrm{~g}$ spiramycin per $50 \mathrm{~kg}$ of the mineral mixture. Another 274 cows and their calves were used as controls on a separate pasture and received the mineral mix without the antibiotic. An evaluation of the efficiency of the prophylactic measures was made by repeated examination of the maxillary gingiva of the calves in each treatment group. The last examination was performed at weaning, when the calves were 7 to 8 months old. No periodontal lesions were found in the calves from the mineral mix plus antibiotic treatment groups, whereas in the control groups the prevalence of periodontal lesions was 10.8 and $5.1 \%$ respectively.
The efficacy of virginiamycin, an antibiotic that is poorly absorbed by the digestive tract, was tested as a prophylactic for the disease on a Cl-prone farm, in the State of São Paulo (Canaã, county of Barretos), where the incidence of $\mathrm{CI}$ was 51,1\% in 1990 (Dutra et al. 1992). In January 1991, 60 recently born calves with their mothers were divided randomly into two groups of equal number. One of the groups received $0.032 \mathrm{~g}$ of virginiamycin orally, twice a week. The other 30 calves, kept together with the first group and under the same conditions of management, were not treated. All the calves were examined every 2 weeks for 5 months. The treated group did not show any alterations of the gingiva, whilst $30 \%$ of the non-treated calves developed periodontal lesions. From June 1991 on, 150 young calves received virginiamycin continuously as additive in a mineral supplement. In the 6 following months, the animals were examined each fortnight, but none of them showed periodontal lesions. In late November, the use of virginiamycin in the mineral mixture was discontinued and $20 \%$ of the calves had developed periodontal Cl-lesions 4 months later.

These experiments showed that spiramycin and virginiamycin can control Cl effectively.

The successful prevention of $\mathrm{Cl}$ by the antibiotics added to the mineral supplement, confirms the importance of the isolated bacteria in the development of the disease. Page \& Schroeder (1982), in their review on Periodontitis in Man and Other Animals, stressed that without colonization of bacteria on the marginal gingiva the periodontal lesions can not develop. These same authors also wrote in their review, regarding CI-periodontitis: "It is notable however that disease symptoms (of $\mathrm{CI}$ ) found around premolars and molars are typical of those caused by infection, especially when seen in the light of comparative pathology".

18. Efficacy of orally administered virginiamycin for the recovery of calves from $\mathrm{Cl}$-periodontitis

On a former Cl-prone farm in the State of São Paulo (Santa Fé, county of São Carlos), 77 calves with progressive periodontal Cl-lesions, maintained under conditions which led to a $61.5 \%$ incidence of the disease, received $0.032 \mathrm{~g}$ of virginiamycin per dose, 3 times a week orally for 8 weeks. Two groups of Cl-diseased calves were used as controls. One, consisting of 10 calves, was kept within the treatment group but did not receive the antibiotic; the second group, consisting of 95 calves, was maintained under the conditions in which $\mathrm{Cl}$ occurred on the farm. At the end of the period of administration of virginiamycin, healing of the periodontal lesions and a great improvement in general health was seen in the treated group, whilst the animals of the two control groups revealed aggravation of the disease, with loss of teeth, continuing putrid odor from oral cavity, diarrhea and emaciation. It was concluded, that orally administered virginiamycin was effective as treatment for the recovery of calves from Cl-periodontitis. (Tims et al. 1992)

19. "Cara inchada" and cellular immunity As the bacteriological studies indicated, the bacteria of 
the Bacteroides melaninogenicus group, with their enzymes and endotoxins, are mainly responsible for the $\mathrm{Cl}$-periodontitis (Blobel et al. 1984, 1987, Dutra et al. 1986). The question that arises is what allows the bacteria which can be isolated in small numbers from the marginal gingiva of healthy cattle raised on CI-free farms (Blobel et al. 1984, Grassmann et al. 1997, I.S. Dutra, unpublished data), to become pathogenic and cause the progressive periodontitis? Schmitt et al. (1996) investigated a possible relationship between the cellular immunity of cattle and $\mathrm{Cl}$. They found that adherence of the black-pigmented B.melaninogenicus group to polymorphonuclear granulocytes and phagocytosis of the bacteria were diminished in calves with $\mathrm{Cl}$. One could conclude that these immunological alterations might possibly predispose cattle to the periodontitis.

20. Modification of the soil microflora after the first cultivation of virgin soils or after new cultivation of longstanding undisturbed soils in former CI-prone areas

Studies about the modification of the soil microflora, after the first cultivation of the virgin "Cerrado" in central-western Brazil during the late 1970s, revealed a significant increase in the number of actinomycetes (Baldani et al. 1982). These authors were interested in the modification of the soil microflora, because this phenomenon hampered the efficiency of biological nitrogen fixation by Rhizobium (now Bradyrhizobium sp) in soybeans during the initial years after the first cultivation of the virgin "Cerrado". They found that efficient strains of rhizobia were streptomycin-resistant, and they deduced from this that there is an increased production of streptomycin in the disturbed virgin soil by the large increase in actinomycetes, including the genus Streptomyces. This phenomenon is partially due to the availability of abundant decaying, organic matter in the disturbed soil.

On a former Cl-prone farm in the State of São Paulo (Santa Fé, county of São Carlos), an outbreak of $\mathrm{Cl}$ occurred during the dry season after cattle were fed with sugar cane grown on a newly ploughed, limed and fertilized area, as a supplement to the dry pasture (Dutra et al. 1993). In a recently cultivated area sown to soybeans, close to the sugar cane plantation, soil samples were collected to study the possible increase of actinomycetes under these conditions. Huddleston et al. (1997) identified all the isolated actinomycetes from these samples as Streptomyces spp, and half of the strains of rhizobia isolated from the soybeans were resistant to streptomycin. The increase in resistance among the soybeanrhizosphere isolates was thought to be related to avoiding inhibition by the onset of streptomycin production. Leitão (1983) also reported on the high population of Streptomyces spp in the "Cerrado" soils, the well known antibiotic effect of these microorganisms on rhizobia, and the high resistance against streptomycin of efficient strains for nitrogen fixation of Rhizobium (Bradyrhizobium) japonicum. From these findings, it could be deduced, (1) that there is an increased streptomycin production in former virgin soils cultivated for the first time, (2) there is a similar streptomycin production in soils left idle for many years but disturbed again by new cultivation, and (3) that streptomycin might be a factor in the pasture or forage that would allow the development of Cl-periodontitis. For example, it was most likely present in the sugar cane given to the cattle of the Cl-outbreak on the above mentioned farm Santa Fé.

It would be interesting to know how long this modified soil microflora and the increased streptomycin production
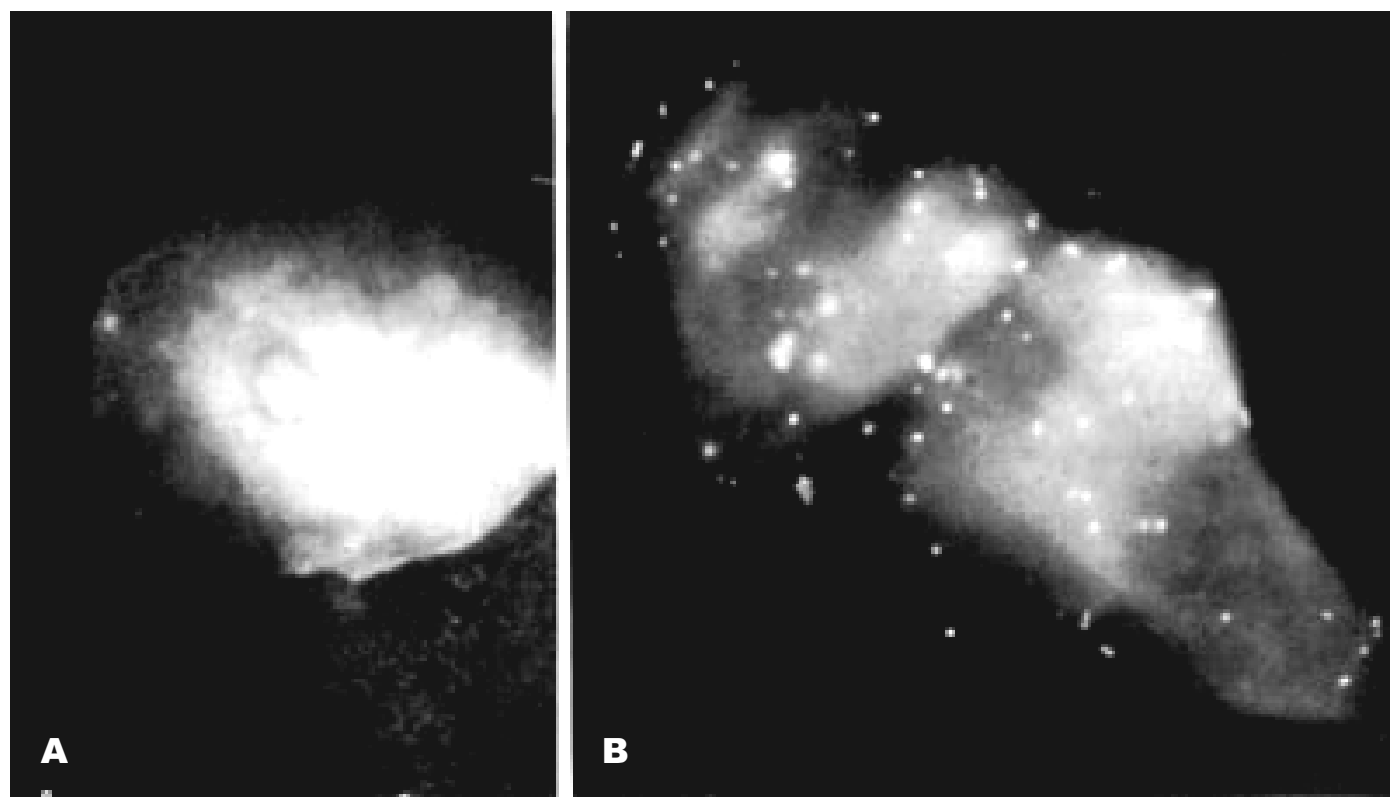

Fig.19. Result of the "in vitro"-assay of adherence of Bacteroides melaninogenicus, previously treated with subinhibitory concentrations of streptomycin, to gingival epithelial cells of cattle: (A) absence of adherence of non-treated B. melaninogenicus, and (B) clear adherence of B. melaninogenicus treated with streptomycin. Marking with fluoresceine isocyanate, obj.100. (From Kopp et al. 1996) 
lasts before they return to normal. This whole phenomenon in those soils fits very well into the epizootiology of CI. It is possible that streptomycin has a great effect on the development of the periodontitis by modifying the bacteria of the subgingival space, giving the Bacteroides group a chance to become pathogenic. Less streptomycin production as soil microflora returns to normal after cultivation would also explain the decrease and disappearance in the incidence of $\mathrm{Cl}$ in recent years. In the late 1980 s less agricultural land was gained through cultivation of virgin soils in natural forest and "errado"-areas of the Brazilian hinterland, because of improved environmental protection and reduction in the financial incentives to cultivate new land.

From these data one could now postulate that the soil microflora in former $\mathrm{Cl}$-prone areas returns to normal again after a few years. The supposed determinant factor for the development of the infectious periodontitis -i.e., the increase in number of actinomycetes, including streptomycetes, and therefore the enhanced production of antibiotics in the soil, - finally ceases.

21. Streptomycin and actinomycin increase the adherence on oral epithelial cells of the Bacteroides melaninogenicus group associated with the periodontal Cl-lesions

In order to study the importance of streptomycin for the pathogenesis of the Cl-periodontitis, the possible effect of the antibiotic on the adherence of the Bacteroides melaninogenicus group and of Actinomyces pyogenes to oral epithelial cells of cattle was assessed "in vitro", together with streptococci of the viridans-group and in different combinations (Kopp et al. 1996). It was found that in subinhibitory concentrations, streptomycin increased the rate of adherence of Gramnegative, black-pigmented $B$. melaninogenicus, tenfold from 0.4 to 4.0 bacteria per bovine oral epithelial cell (Fig. 19). However, streptomycin did not significantly influence the adherence of the Gram-positive A.pyogenes nor the Grampositive streptococci of the viridans- group. Thus, streptomycin could be an important contributing factor to the development of the periodontal infections of $\mathrm{CI}$. The possible adherence of the anaerobic Bacteroides spp to the sulcus epithelium and possibly also to the tooth surface in the subgingival space would favor the formation of bacterial plaques. This could lead to the onset and development of the inflammatory process and destruction of the periodontal tissues.

In subsequent "in vitro"-assays, Grassmann et al. (1997) showed that besides streptomycin, actinomycin and antibiotic culture supernatants of soil actinomycetes significantly increased the adherence of the B.melaninogenicus group to the oral epithelial cells of calves. Again, there appeared to be a correlation between the antibiotic activities in the soil and the development of $\mathrm{Cl}$-periodontitis. Most of the actinomycetes isolated from soil of Cl-positive farms were identified biochemically as streptomycetes.

However, the "in vivo" exposure (Grassmann et al. 1997) of about 1 month-old calves to streptomycin, actinomycin and the antibiotic supernatants, together with B.melaninogenicus and $A$. pyogenes, for an observation period of 20 days, failed to lead to any progressive lesions in the periodontium. This could be explained by the relatively short time of exposure, low frequency of applications and possibly unsuitable antibiotic concentrations compared to natural conditions. Nevertheless, it was confirmed "in vitro" that antibiotics produced by soil actinomycetes significantly enhanced the adherence of $\mathrm{Cl}$-associated bacteria to the host gingival epithelial cells providing strong evidence that these antibiotics play a role as a determinant factor in the pathogenesis of the multifactorial infectious Cl-periodontitis.

\section{Final considerations}

Field observations and experiments have been of most importance in understanding the epidemiology of multifactorial, infectious periodontitis and the development of $\mathrm{Cl}$ in calves. Ever since the occurrence of large outbreaks of the disease, after the utilization by cattle farmers of former virgin forest and "Cerrado" areas in central-western and northern Brazil, in the late 1960 s and the 1970 s, many veterinarians and research workers considered $\mathrm{Cl}$ to be of nutritional origin. Mineral deficiencies or imbalances of mainly calcium and phosphorus were blamed. A commercial mineral mixture, apparently containing an antibiotic additive, reduced the incidence of the disease to some extent. Its favourable action, observed on CI-prone farms and supported by one unpublished field-experiment carried out by J.C. Sousa in Mato Grosso do Sul, reinforced the belief that the disease is caused by an undefined mineral deficiency or imbalance. However many characteristics of the disease in the field failed to support this hypothesis. For example, the occurrence and epidemiology of Cl-periodontitis show that it improves in all areas with time. A relatively high incidence $\mathrm{Cl}$ could be observed on clay soils for many years, with only a slow decrease in the number of cases after 5 years or more. On the other hand, although the initial incidence could also be high on sandy soils, the disease almost disappeared after 3 years. An explanation might be that the antibiotics produced by the actinomycetes are adsorbed onto the clay and only gradually released over a long period. Mineral problems would almost certainly be worse on sandy soils and deteriorate with time.

$\mathrm{Cl}$ was the disease that caused most of the losses suffered by cattle farmers in the 1970s in central-western and northern Brazil. Since then, the disease declined sharply in incidence and has almost disappeared. This is confirmed by no mention of $\mathrm{Cl}$ in the recently published book on "Principal Diseases of Beef Cattle in Mato Grosso do Sul" (Lemos 1998).

Cl-periodontitis could not be reproduced in confined young calves at the Institute in Rio de Janeiro (Grassmann et al. 1997). The natural conditions of ingestion of the antibiotics in subinibitory concentrations are most difficult if not impossible to imitate. In our view, it should be possible to reproduce the disease under to some extent controlled conditions on former Cl-prone farms, where the soil, undisturbed for many years, has been freshly cultivated to improve the pasture growth or forage production. Such "controlled" conditions existed in the natural outbreaks of $\mathrm{CI}$, which occurred on the farms Santa Fé and Canaã, in the Barretos and São Carlos areas of the State of São Paulo (Dutra et al. 1993). In one of 
these farms (Santa Fé), a significant increase in the count of soil actinomycetes was obtained after plowing, grading, liming and fertilizing of the soil and sowing soybeans (M.C.P. Neves, unpublished data; Pereira 1995). This area was close to the improved sugar cane plantation used for feeding the cattle during the dry season, a practice that led to the previously mentioned severe $\mathrm{Cl}$-outbreak.

It is of interest, that bacteria of the Bacteroides melaninogenicus group could also be isolated, even though in much smaller numbers, from the marginal gingiva of some healthy calves on Cl-free farms (Blobel et al. 1984, Dutra \& Grassmann, unpublished data). This again indicates that onset and development of the inflammatory process at the marginal gingiva depends on the presence of a determinant factor in the pasture or forage. Our investigations provide strong evidence, that this determinant factor arises with the modification of the soil microflora resulting from the recent cultivation of virgin soils or old pasture. In these situations, soil actinomycetes can be favored to increase rapidly in number and produce antibiotics like streptomycin and actinomycin. These antibiotics ingested in subinhibitory doses with the forage, and apparently passing in the milk to calves, have been shown to significantly enhance the "in vitro" adherence of the B.melaninogenicus group to epithelial cells of the bovine gingiva. This logical sequence of explanations suggest that $\mathrm{CI}$ should now be defined as an infectious periodontitis, most likely determined by the increased production of antibiotics in the soil.

The addition of spiramycin and virginiamycin to mineral supplements was effective for the prophylaxis of $\mathrm{CI}$. Oral administration of virginiamycin was also an effective treatment. So it is recommended that pasture or forage cultivated on recently disturbed virgin or long-standing undisturbed soils in potential Cl-areas should be avoided for calf raising, unless an efficient antibiotic is added to the mineral supplement.

In the discussion of their comparative review on Periodontitis in Man and Other Animals, Page \& Schroeder (1982) made several statements, which are important for the consolidation of our conclusions on the etiology and pathogenesis of CI. They wrote: (1) Without exception, mammalian periodontitis is caused by bacteria. ... (2) Pocket formation is an universal manifestation of periodontitis in man and all other mammalian species in which the disease occurs. ... (3) Pocket formation is caused by the presence and invasion of bacteria, not by traumatic occlusal forces, stress, or nutritional or hormonal abnormalities. Pockets do not form in germ-free animals and they cannot be induced experimentally in absence of the bacteria. (4) Pocket formation does not occur as a consequence of resorption of the alveolar bone. ... (5) Pathologic resorption of the alveolar bone is a feature of periodontitis in all mammalian species ... and without exception, this resorption is accompanied by an acute inflammation ... (6) In all species, formation of gingival and periodontal pockets is accompanied by disruption of the attachment between the junctional epithelium and the tooth surface. The same authors stated in their chapter Periodontal Infections, the Microbial Attack: "Periodontitis initiated or perpetuated by causes other than bacteria has not been demonstrated in any mammalian species. Genco (1981) concluded that recent microbiological studies supported the concept 'that various forms of periodontal disease represent infections by different specific groups of microorganisms', ... administration of antibiotics can prevent or reverse periodontitis in experimental animals." In the chapter Pocket Formation and Deepening, Page \& Schroeder (1982) stressed: "... resorption of the alveolar bone does not cause pocket formation. On the contrary, bacteria are the driving force behind pocket formation, and pocket formation results in loss of attachment and bone resorption." These statements give considerable support to our hypothesis reached on the etiopathogeny of Cl-periodontitis.

Summarizing, the following can be said to the etiology of $\mathrm{Cl}$ :

- Cl-periodontitis does not occur without the presence of a specific group of microorganisms;

- Anaerobic bacteria of the black-pigmented Bacteroides melaninogenicus, together with Actinomyces pyogenes, predominate in the rapidly progressive periodontal Cl-lesions;

- There is a marked regression of the specific, pathogenic microflora in the periodontal pouch of cattle transferred from CI-prone to CI-free areas;

- A straight correlation exists between the clinical healing of CI-lesions and the bacteriological cure;

- The specific group of microorganisms isolated from $\mathrm{Cl}$ lesions forms a part, though in minute proportions, of the subgingival microflora of healthy cattle;

- The principal bacteria isolated from actively progressing periodontal Cl-lesions produce enzymes, toxins and lipopolysaccharides with the direct or indirect potential to destroy tissue and cause bone resorption;

- The initial periodontal CI-lesions occur generally at the apex of the interdental papillae, initially between the second and the third erupting, deciduous premolar teeth $\left(\mathrm{Pd}_{3}-\mathrm{Pd}_{4}\right)$ in young calves. As the disease has its onset during tooth eruption, in yearling cattle transferred to $\mathrm{Cl}$-prone pastures the periodontal lesions develop at the molars;

- The lateral enlargement of the maxillary bones ("cara inchada") is due to an ossifying periostitis and depends on the development of the inflammatory process at the periodontium;

- There is no any evidence that $\mathrm{Cl}$ is a nutritional disease, and there is no proven relationship with a mineral deficiency or imbalance;

- $\mathrm{CI}$ can be controlled by the oral administration of an effective antibiotic (spiramycin, virginiamycin), or as an additive to any mineral supplement;

- The occurrence of $\mathrm{Cl}$ is directly related to the recent cultivation of virgin soils, in certain regions above a latitude which includes the states of Mato Grosso do Sul and São Paulo, Brazil;

- Outbreaks of CI may nowadays also occur, when longstanding undisturbed soils in former Cl-prone areas are newly cultivated to impove pasture formation and forage growth; 
- The incidence of $\mathrm{CI}$ has drastically declined in the last decade, and the disease has naturally disappeared in most former $\mathrm{Cl}$-prone areas.

Based on all these data, it can be concluded that $\mathrm{Cl}$ is due to an infectious, rapidly progressive periodontitis, with participation of the Bacteroides melaninogenicus group, i.e., of anaerobic, Gram-negative, non-sporulating, non-saccharolytic bacteria, often together with Actinomyces pyogenes. These bacteria also occur in the gingival microflora of healthy cattle. The onset and development of the periodontitis in young calves is linked to the presence of Bacteroides spp in the subgingival space, the anatomical features of the periodontium ("ecological niches"), the period of tooth eruption, a possible response of the host defense system, and mainly by an environmental-dependant determinant factor apparently present in the forage and also carried in milk. There is now strong evidence that this determinant factor arises from the modification of the soil microflora and consists of antibiotics produced in larger quantities by an increased number of soil actinomycetes. Subinibitory concentrations of streptomycin and of actinomycin, as produced in the soil, cause the enhanced adherence of B.melaninogenicus to bovine gingival epithelial cells "in vitro". This group of bacteria is always isolated in large numbers from the periodontal Cl-lesions and can easily explain the etiopathogeny of this multifactorial infectious disease intimately related to disturbance of the soil ecology.

Acknowledgements.- This review on the "cara inchada"-disease of cattle (CI) results to a great extent from the many field experiments performed on farms in the states of Mato Grosso, Mato Grosso do Sul and São Paulo, in the 1970s and 1980s, to investigate the epizootiology of the disease and to elucidate its etiology. Our thanks to all the farmers who gave us their support in this investigation, especially to the owners of the farms Santa Escolástica, Santo Antonio do Jurigue, Paulicéia and São Manoel, situated in the Rondonópolis-area of Mato Grosso, and also to the owners of the farms Buriti, Mato Grosso do Sul, and Recreio, São Paulo. We would also like to thank the Extension Service CATI and the Nestlé Company for their support during our investigation on small dairy cattle farms in the São Simão area, São Paulo. Our special acknowledgements to the agronomists Afonso Nogueira Simões Corrêa, Jerônimo Alves Chaves (Condepe-Conselho Nacional de Desenvolvimento Pecuário, Campo Grande, MS) and Gabriel Miranda dos Anjos (Emater/ MT-Empresa de Assistência Técnica e Extensão Rural de Mato Grosso, Cuiabá, MT), who gave assistance with our transportation by car and airplane to reach the numerous and most distant farms where $\mathrm{Cl}$ occurred in centralwestern and northern Brazil. We thank the Brazilian National Research Council (CNPq) for the valuable research fellowships and support of consultants. Our acknowledgements to the German Service for Academic Exchange (DAAD) for backing the consultants and studies in Germany, which made a fruitful cooperation with the Veterinary Faculties of the Justus-Liebig-University Giessen (Bacteriology and Immunology: Prof.Dr.H.Blobel), the LudwigMaximilians-University München (Institut of Histology: Prof.Dr.P.Walter) and the Free University Berlin (Institut of Veterinary Pathology: Prof. Dr. K.Dämmrich), all possible.

\section{REFERENCES}

Baldani J.L., Baldani V.L.D., Xavier D.F., Boddey R.M. \& Döbereiner Joh. 1982. Efeito da calagem no número de actinomicetos e na porcentagem de bactérias resistentes à estreptomicina na rizosfera de milho, trigo e feijão [Effect of liming on the number of actinomycetes and the percentage of bacteria resistant to streptomycin in the rhizosphere of maize, wheat and beans]. Revta Microbiologia, São Paulo, 13:250-263.
Blobel H., Döbereiner J., Lima F.G.F. \& Rosa I.V. 1984. Bacterial isolations from "cara inchada"-lesions of cattle. Pesq. Vet. Bras. 4(2): 73-77.

Blobel H., Döbereiner J., Rosa I.V., Lima F.G.F. \& Dutra I.S. 1987. Bakteriologische Untersuchungen an der "cara inchada", einer parodontalen Erkrankung der Jungrinder in Brasilien [Bacterial investigations of a periodontal disease - cara inchada - in Brazilian cattle]. Tierärztl. Umschau 42: 152157.

Botteon R.M., Dutra I.S., Döbereiner J. \& Blobel H. 1993. Caracterização de bactérias anaeróbias isoladas de lesões peridentárias da "cara inchada" dos bovinos [Characterization of anaerobic bacteria isolated from periodontal lesions of "cara inchada" in cattle]. Pesq. Vet. Bras. 13(3/4): 51-55.

Brito L.A.B. 1983. Aspectos morfológicos da "doença periodontal" em bovinos [Morphological aspects of the "periodontal disease" in cattle]. M.Sc.Thesis, Esc.Veterinária UFMG, Belo Horizonte.

Döbereiner J. 1990. Zur Ätiologie der "Cara inchada", einer parodontalen Erkrankung der Jungrinder in Brasilien [Towards the etiology of "cara inchada", a periodontal disease of young cattle in Brazil]. Dtsch. Tierärztl. Wschr. 97: 482-490.

Döbereiner J. \& Dämmrich K. 1997. Are alveolar changes a determinant factor for "cara inchada" in cattle? Pesq. Vet. Bras. 17(2): 45-48.

Döbereiner J., Inada T. \& Tokarnia C.H. 1974. "Cara inchada", doença peridentária em bovinos ["Cara inchada”, a periodontal disease in cattle]. Pesq. Agropec. Bras., Sér. Vet. 9: 63-85.

Döbereiner J., Chaves J.A.. Rosa I.V. \& Houser R.H. 1975. Efeito da transferência de bovinos com "cara inchada" (Doença peridentária) para pastos de região indene [Effect of the transference of cattle affected by "cara inchada" (periodontal disease) to pasture-land free of the disease]. Pesq. Agropec. Bras., Sér. Vet. 10: 99-103.

Döbereiner J., Rosa I.V. \& Lazzari A.A. 1976. "Cara inchada” (doença peridentária) em bezerros mantidos em pastos de Panicum maximum ["Cara inchada" (periodoental disease) in calves kept on Panicum maximumpastures]. Pesq. Agropec. Bras., Sér. Vet. 11: 43-47.

Döbereiner J., Schenk J.A.P. \& Briso J.L. 1978. Experimento com bezerros afetados pela "cara inchada" (doença peridentária) em pasto formado sem emprego de fogo [Experiment in calves affected by "cara inchada" (periodontal disease) on a pasture cultivated without the use of fire]. XVI Congr. Bras. Med. Vet., Salvador, Bahia. (Resumo)

Döbereiner J., Rosa I.V. \& Lazzari A.A. 1987. Efeito do leite materno sobre as lesões peridentárias da "cara inchada" em bezerros [Effect of the milk from cows on the periodontal lesions of their calves affected by "cara inchada"]. Pesq. Vet. Bras. 7(3): 97-99.

Döbereiner J., Rosa I.V., Dutra I.S., Pereira A.R. \& Blobel H. 1990. Efeito de espiramicina na profilaxia da "cara inchada" dos bovinos [Effect of spiramycin in the prophylaxis of "cara inchada" in cattle]. Pesq. Vet. Bras. 10(1/2): 27-29.

Driemeier D., Barros S.S., Peixoto P.V., Tokarnia C.H., Döbereiner J. \& Brito M.F. 1998. Estudos histológico, histoquímico e ultra-estrutural de fígados e linfonodos de bovinos com presença de macrófagos espumosos ("foam cells") [Histological, histochemical and ultra-structural studies in livers and lymph nodes of cattle with the presence of foam cells]. Pesq. Vet. Bras. 18(1): 29-34.

Driemeier D., Döbereiner J., Peixoto P.V. \& Brito M.F. 1999. Relação entre macrófagos espumosos ("foam cells") no fígado de bovinos e ingestão de Brachiaria spp no Brasil [Correlation between foam cells in the liver of cattle and the ingestion of Brachiaria spp in Brazil]. Pesq. Vet. Bras. 19(2): 79-83.

Dutra I.S. \& Döbereiner J. 1992. Efficacy of virginiamycin for the prophylaxis of "cara inchada", a periodontal disease of cattle. XIII Congr. Panam. Cienc. Veterinárias, Santiago, Chile, p. 337.

Dutra I.S., Kanoe M. \& Blobel H. 1986. Atividades enzimáticas e endotóxicas de bactérias isoladas de lesões peridentárias da "cara inchada" dos bovinos [Enzymatic and endotoxic activities of bacteria isolated from periodontal lesions of "cara inchada" in cattle]. Pesq. Vet. Bras. 6(2): 59-63.

Dutra I.S., Matsumoto T. \& Döbereiner J. 1993. Surtos de periodontite em bezerros ("cara inchada") associados ao manejo do solo [Outbreaks of 
periodontitis in calves ("cara inchada") associated with soil management]. Pesq. Vet. Bras. 13(1/2): 1-4.

Dutra I.S., Botteon R.C.M. \& Döbereiner J. 2000. Modificação da microbiota associada às lesões peridentárias da "cara inchada" em bezerros transferidos para área indene [Modification of the microflora associated with the periodontal lesions of "cara inchada" in calves transferred to a diseasefree area. Pesq. Vet. Bras. 20(2):71-74.

Genco R.J. (1981). Progress in periodontal research. Findings from the Periodontal Disease Clinical Research Center, State University of New York at Buffalo. Northeast Soc. Periodontist Bull. 11: 5-14. (Cited by Page \& Schroeder 1982)

Giovine N., Rangel N., Machado A.V., Lamounier R.D. \& Wilwerth A. 1943. Necrobacilose. Súmula nosológica, a necrobacilose em Minas Gerais, Brasil [Necrobacillosis. A nosological summary, necrobacillosis in Minas Gerais, Brazil]. Arqs Esc. Sup. Vet. Minas Gerais, Belo Horizonte, 1: 35-65.

Grassmann B., Döbereiner J., Dutra I.S., Kopp P.A. \& Blobel H. 1997. Adherence and experimental infection of bacteria associated with periodontal infections of young cattle in Brazil ("Cara inchada"). Pesq. Vet. Bras. 17(3/ 4): 123-125.

Huddleston A.S., Cresswell N., Neves M.C.P., Beringer J.E., Baumberg S., Thomas D.I. \& Wellington E.M.H. 1997. Molecular detection of streptomycinproducing streptomycetes in Brazilian soils. Appl. Environ. Microbiol. 63(4): 1288-1297.

Kopp P.A., Dutra I.S., Döbereiner J., Schmitt M., Grassmann B. \& Blobel H. 1996. Estreptomicina aumenta a aderência em células epiteliais de Bacteroides melaninogenicus associado às lesões peridentárias da "cara inchada" dos bovinos [Streptomycin enhances the adherence on epitelial cells of Bacteroides melaninogenicus associated with periodontal lesions of "cara inchada" in cattle]. Pesq. Vet. Bras. 16(2/3): 53-57.

Lamounier R.D. \& Pereira P.C. 1945. Sobre o caso de necrobacilose bovina em São Paulo, oriundo de um possível foco [About a case of necrobacillosis in cattle in the state of São Paulo]. Revta Fac. Med. Vet., São Paulo, 3: 165168.

Leitão M.R.S.M.M. 1983. Resistênica a antibióticos de estirpes de Rhizobium japonicum e seu papel na sobrevivência do Rhizobium e nodulação da soja (Glycine max (L) Merril) em solos de cerrados [Resistance to antibiotics of Rhizobium japonicum strains and its importance for survival of Rhizobium and the nodulation of soybean (Glycine max (L) Merril) in "cerrado" soils]. Tese M.Sc., Univ.Fed.Minas Gerais, Belo Horizonte. 133 p.

Lemos R.A.A. 1998. Principais Enfermidades de Bovinos de Corte do Mato Grosso do Sul. Reconhecimento e Diagnóstico [How to recognize and diagnose the main diseases of beef cattle in Mato Grosso do Sul]. Depto Med. Vet., Univ.Fed.Mato Grosso do Sul, Campo Grande, MS.

Moraes S.S., Silva G.N. \& Döbereiner J. 1994. Microelementos minerais e a "cara inchada"dos bovinos [Mineral microelements and "cara inchada" in cattle]. Pesq. Vet. Bras. 14(1): 25-33.

Nunes V.A. 1996. Doença periodontal (cara inchada) dos bovinos [Periodontal disease (cara inchada) in cattle]. Cad. Téc. Esc. Vet. UFMG, Belo Horizonte, no. 15: 5-26.

Nunes V.A., Viana J.A.C., Carvalho A.U., Santos B.M., Ribeiro H.M. \& Teixeira T. 1979. Doença periodontal (cara inchada) em bovinos do Estado de Goiás. I. Aspectos morfológicos [Periodontal disease (cara inchada) of cattle in the state of Goiás. I. Morphological aspects]. Arqs Esc. Vet. UFMG, Belo Horizonte, 31(3): 283-296

Page R.C. \& Schroeder H.E. 1982. Periodontitis in Man and Other Animals. A Comparative Review. Karger, Basel. 330 p.

Pereira J.C. 1995. Ecologia da comunidade bacteriana em solos de Cerrados [Ecology of the bacterial community in Cerrado-soils]. Tese de Doutoramento, Univ. Fed. Rural do Rio de Janeiro, Seropédica, RJ. 172 p.

Rosa I.V. \& Döbereiner J. 1994. "Cara inchada" dos bovinos e deficiências minerais ["Cara inchada" in cattle and mineral deficiencies]. Pesq. Vet. Bras. 14(1): $43-48$.

Rosa I.V., Carvalho J.C., Houser R.H. \& Döbereiner J. 1976. Influência de ração balanceada sobre a "cara inchada" (doença peridentária) de bezerros [Influence of a balanced ration on "cara inchada" (periodontal disease) in calves]. Pesq. Agropec. Bras., Sér. Vet. 11: 59-63.

Rosa I.V., Döbereiner J. \& Blobel H. 1985. O efeito de tratamento com antibióticos sobre as lesões peridentárias da "cara inchada" dos bovinos [Effect of parenteral treatment by antibiotics on the periodontal lesions of "cara inchada" in cattle]. Pesq. Vet. Bras. 5(1): 5-9.

Schmitt M., Dutra I.S., Döbereiner J., Kopp P.A. \& Blobel H. 1996. "Cara inchada" and cellular immunity in cattle. Pesq. Vet. Bras. 16(1):1-3.

Seifert K., Walter P., Döbereiner J. \& Rüsse I. 1983. Histological investigations of "cara inchada" in cattle. Pesq. Vet. Bras. 3(2): 67-70.

Shah H.N. \& Collins D.M. 1988. Proposal for re-classification of Bacteroides asaccharolyticus, Bacteroides gingivalis, and Bacteroides endodontalis in a new genus, Porphyromonas. Int. J. Syst. Bacteriol. 38:128-131.

Shah H.N. \& Collins D.M. 1989. Proposal to restrict the genus Bacteroides (Castellani and Chalmers) to Bacteroides fragilis and closely related species. Int. J. Syst. Bacteriol. 39: 85-87.

Shah H.N. \& Collins D.M. 1990. Prevotella, a new genus to include Bacteroides melaninogenicus and related species formerly classified in the genus Bacteroides. Int. J. Syst. Bacteriol. 40:205-208.

Silva L.B. 1989. Alterações hepáticas em bovinos acometidos de "doença periodontal" (cara inchada) [Hepatic changes in cattle affected by the periodontal disease "cara inchada"]. Tese de Mestrado, Univ. Fed. Minas Gerais, Belo Horizonte. 27 p.

Soni C.A. 1984. Influência do cálcio, do fósforo e do cobre na "doença periodontal" do bovino [Influence of calcium, phosphorus and copper on the "periodontal disease" in cattle]. Tese de Mestrado, Univ. Fed. Minas Gerais, Belo Horizonte. 51 p.

Sousa J.C., Gomes R.F.C., Vianna J.A.C., Nunes V.A., Schenk J.A.P., Rosa I.V. \& Guimarães E.D. (1986). Suplementação mineral dos bovinos com doença periodontal ("cara inchada"). 1. Aspectos nutricionais. Revta Soc. Bras. Zootec. 15(1): 1-16.

Souza W.T.F. 1987. Aspectos morfológicos do fêmur, do úmero e de vértebras lombares em bovinos jovens afetados de "doença periodontal" [Morphological aspects of femur, humerus and lumbar vertebrae of young cattle affected by "periodontal disease"]. Tese de Mestrado, Univ. Fed. Minas Gerais, Belo Horizonte. 46 p.

Tims F.M., Dutra I.S.,Matsumoto T. \& Döbereiner J. 1992. Eficiência de virginiamicina na recupereação de bezerros com a doença peridentária "cara inchada" [Efficiency of virginiamycin for the recovery of calves from the periodontal disease "cara inchada”]. Pesq. Vet. Bras. 12(3/4): 77-80. 